\title{
Predicting Soybean Rust Incursions into the North American Continental Interior Using Crop Monitoring, Spore Trapping, and Aerobiological Modeling
}

\author{
S. A. Isard, Departments of Plant Pathology and Meteorology, Pennsylvania State University, University Park; C. W. Barnes, Escuela \\ de Biología, Pontificia Universidad Católica del Ecuador, Quito, Ecuador; S. Hambleton, Agriculture and Agri-Food Canada, Ottawa, \\ ON; A. Ariatti, Department of Plant Pathology, Pennsylvania State University, University Park; J. M. Russo, President, ZedX Inc., \\ Bellefonte, PA; A. Tenuta, Ontario Ministry of Agriculture, Food, and Rural Affairs, Ridgetown, ON; D. A. Gay, National Atmospheric \\ Deposition Program, Illinois State Water Survey, University of Illinois, Champaign; and L. J. Szabo, Cereal Disease Laboratory, U.S. \\ Department of Agriculture-Agricultural Research Service, and University of Minnesota, St. Paul, MN
}

\begin{abstract}
Isard, S. A., Barnes, C. W., Hambleton, S., Ariatti, A., Russo, J. M., Tenuta, A., Gay, D. A., and Szabo, L. J. 2011. Predicting soybean rust incursions into the North American continental interior using crop monitoring, spore trapping, and aerobiological modeling. Plant Dis. 95:1346-1357.

Between 2005 and 2009, millions of U.S. and Canadian soybean acres that would have received fungicide application remained untreated for soybean rust due to information disseminated through the Integrated Pest Management Pest Information Platform for Extension and Education (ipmPIPE), increasing North American producers' profits by hundreds of millions of dollars each year. The results of our analysis of Phakopsora pachyrhizi urediniospores in rain collections, aerobiology model output, and observations of soybean rust spread in 2007 and 2008 show a strong correspondence between spore collections and model predictions for the continental interior of North America, where

soybean is an important crop. The analysis suggests that control practices based on up-to-date maps of soybean rust observations and associated commentary from Extension Specialists delivered by the ipmPIPE may have suppressed the number and strength of inoculum source areas in the southern states and retarded the northward progress of seasonal soybean rust incursions into continental North America. The analysis further indicates that spore trapping and aerobiological modeling can reduce our reliance on the costly Sentinel Plot Network while maintaining the effectiveness of the ipmPIPE system for soybean rust management.
\end{abstract}

Soybean rust (SBR), caused by the obligate parasite Phakopsora pachyrhizi Sydow, is regarded as the most destructive foliar disease of soybean (Glycine max (L.) Merr.). The disease is spread by urediniospores that can be transported long distances by winds $(23,28)$ and may remain viable in the air for many days if they are protected from ultraviolet radiation by cloud cover (15). SBR was first identified in the continental United States in 2004 (34), having spread over the previous century from eastern Asia to Australia, India, Africa, and South America. In late September 2004, P. pachyrhizi urediniospores were likely blown by winds from northern South America to the southeastern United States and deposited by rain associated with Hurricane Ivan (16).

At least 95 species of legumes are susceptible to SBR infection based on inoculation studies (3), with field reports of the disease on soybean and kudzu (Pueraria montana) predominating in the United States (36). During the past six winters, $P$. pachyrhizi has survived in the United States along the Gulf Coast on kudzu $(22,30,36)$. In each of the following years, it spread throughout soybean production areas in the southern United States and into the continental interior of North America, causing infection in soybean as far north as Ontario in 2007 (36).

Prior to 2004 and in anticipation of the arrival of soybean rust in the United States, the USDA funded several studies of its global movement and likely invasion scenarios (16). The same agency also funded an innovative Soybean Rust website, later called the Integrated Pest Management Pest Information Platform for Extension and Education (ipmPIPE), which was launched in mid-March

Corresponding author: S. A. Isard, E-mail: sai10@psu.edu

Accepted for publication 9 June 2011

doi:10.1094/PDIS-01-11-0034

This article is in the public domain and not copyrightable. It may be freely reprinted with customary crediting of the source. The American Phytopathological Society, 2011
2005 (20). Included in the ipmPIPE design was a vigilant continental-scale disease monitoring network coupled with national and state specific guidelines for efficacious fungicide management practices (36).

As part of the ipmPIPE design, an extensive system was established to monitor for disease symptoms on a frequent basis throughout the period when the soybean crop was at risk from the pathogen. The goal was to demarcate the geographic extent and severity of SBR in the United States and Canada as it changed throughout the growing season (20). This system included observations of SBR in sentinel plots (small areas planted to a susceptible host in advance of the local commercial crop), kudzu patches, and commercial fields. The monitoring program, known as the Sentinel Plot Network, has subsequently expanded to soybean production areas in Mexico (36). Because fungicide efficacy requires applications before the disease reaches $5 \%$ incidence on lower-canopy foliage (6), timely communication is necessary for a successful soybean rust control program. The ipmPIPE was paramount to limiting yield losses to soybean rust in North America by providing e-mail warnings, map depictions of movement, and instructive state commentary as to the best control periods and tactics. Threequarters of the crop advisers surveyed in 2007 reported visiting the ipmPIPE, with $80 \%$ visiting the site more than five times (4). Respondents also gave the site overwhelmingly positive reviews in terms of meeting their information needs and felt confident in using the information provided on the website as a basis for management recommendations to growers. In the case of the northern soybean production regions of the United States and Canada, specialists were able to use the ipmPIPE to assure growers that their crop was not at risk from the pathogen. This information averted the use of fungicides that would have been applied unnecessarily to millions of soybean acres (31). Estimates of savings to U.S. soybean growers that have resulted from activities associated with the ipmPIPE vary greatly $(6,31)$ and include a conservative calculation of about $\$ 200$ million per year (9).

Observations of $P$. pachyrhizi urediniospores collected from the air in dry and wet deposition traps $(2,12,23,33)$ have been used to 
supplement the Sentinel Plot Network. Because the number of days between deposition of $P$. pachyrhizi urediniospores and the subsequent appearance of rust pustules is 7 to 10 days under ideal conditions (27) and typically 2 to 3 weeks longer in the field (17), spore trapping can provide valuable information for disease risk assessment. The identification of $P$. pachyrhizi urediniospores in wet deposition collectors is particularly useful for providing early warning of SBR incursions in areas far away from inoculum sources. This is because cloud cover generally associated with strong airflows that produce precipitation blocks much of the ultraviolet radiation, allowing $P$. pachyrhizi urediniospores in the air to remain viable over transport distances of hundreds to thousands of kilometers (1). In addition, rain has the potential to remove spores from an entire air column extending from the top of clouds to the Earth's surface, depositing them onto a host in a wet and cloudy environment suitable for germination and infection (32).

Computer simulation models, such as the Integrated Aerobiology Modeling System (IAMS; 16,19) and the St. Louis University/Iowa State University Rust Prediction Model (29), provide an additional source of information on risk of SBR spread. The IAMS has been run daily during the past six growing seasons, using the observed distribution of SBR-infected areas from the Sentinel Plot Network as input. The IAMS generates a large number of maps including predictions of wet deposition of viable $P$. pachyrhizi urediniospores on soybean and areas at risk for SBR disease development. These maps, posted daily on the ipmPIPE website, are used by state extension pathologists in combination with the observation maps to construct commentary on the risk of SBR spread for their stakeholders (18).

Although the ipmPIPE has clearly been effective for managing SBR, the system is costly to operate and will require a stable, recurring source of funds to support its operation in the next decade $(5,14)$. In 2005, the Sentinel Plot Network spanned 26 states with an average cost of $\$ 40,000 /$ state (13), and a survey of soybean extension pathologists from 31 states suggests that the total funding received for the SBR monitoring program in 2007 was about $\$ 1.6$ million (S. A. Isard, unpublished).

This study has two objectives. The first is to compare and contrast observations of $P$. pachyrhizi urediniospores identified in rain collections from the continental interior of North America with IAMS simulations of wet deposition of viable SBR spores for the 2007 and 2008 growing seasons. The second objective is to provide data to support the premise that spore trapping and aerobiological modeling can reduce our reliance on the costly Sentinel Plot Network while maintaining the effectiveness of the ipmPIPE system for SBR management. For the purposes of this study, the continental interior of North America includes all states and southern portions of Canadian provinces to the north of the line formed by the southern borders of Kansas, Missouri, and Kentucky, between the Appalachian and Rocky Mountains.

\section{Materials and Methods}

Sentinel Plot Network. The Sentinel Plot Network for SBR in the United States and Canada consisted of 751 plots in 2007 and 694 in 2008 (36). More than $80 \%$ of the plots were planted to soybean, with the rest established in wild kudzu patches and other leguminous crops (9). In soybean plots, the cultivar, planting date, and scouting frequency varied throughout the network in accordance with the sentinel plot protocol (36). Two soybean cultivars, one from the maturity group typically used in the surrounding area and the second from an earlier maturing cultivar group were generally planted on dates 1 to 2 weeks earlier than those in the surrounding commercial soybean fields. The monitoring protocol required that 100 leaves from the lower to middle canopy be inspected for SBR by a trained plant pathologist. In a few states, the inspection occurred in the field; however, in the majority of cases, the leaves were incubated for 24 to $48 \mathrm{~h}$ and examined in the laboratory using a microscope. Scouting occurred on a weekly basis once the soybean plants began to flower and continued until they began to senesce. Prior to flowering, scouting was usually less frequent.
The first positive find of SBR in each state was confirmed by the USDA National Plant Diagnostic Network laboratories and in each Canadian province by the Agriculture and Agri-Food Canada rust biosystematics laboratory in Ottawa, using polymerase chain reaction (PCR) assay $(11,24)$. Thereafter, additional positive identifications were confirmed by PCR and/or visually by an extension pathologist (9). In areas threatened by SBR, the Sentinel Plot Network was typically augmented by scouting in commercial fields by extension pathologists. As a result, in 2007 and 2008, the total numbers of locations (sentinel plots, commercial fields, and kudzu patches) scouted for SBR were 12,990 and 16,109 , and the total numbers of observations were 22,176 and 26,103, respectively (36).

Spore collections. Rain was filtered and then assayed for the presence of $P$. pachyrhizi spores in the United States and Canada. In the United States, rain from 75 and 80 National Atmospheric Deposition Program/National Trends Network (NADP/NTN) sites in 2007 and 2008, respectively, was sampled using wet-only precipitation collectors and standard protocols (7). Weekly rain samples spanning the periods 30 May to 11 September 2007 and 7 May to 16 September 2008 were filtered for solids upon collection, processed, and analyzed for the presence of $P$. pachyrhizi DNA as described by Barnes et al. (2). In Canada, 12 and 14 sites in 2007 and 2008, respectively, were equipped with passive rain collectors that were $29 \mathrm{~cm}$ in diameter and designed with a filter assemblage for immediate filtration and spore capture on a cellulose nitrate filter (8.0- $\mu \mathrm{m}$ pore size) in the field (10). Of these sites, five in 2007 and four in 2008 were also equipped with LODA Model 2001 Precipitation Collectors (LODA Electronics, Loda, IL, USA), active precipitation collectors, as used by the NADP/NTN network. Filters from the passive rain collectors and rain from the LODA collectors for weekly collection periods spanning 28 May to 12 October 2007 and 27 May to 14 October 2008 were shipped to the AAFC Eastern Cereal and Oilseed Research Centre in Ottawa, ON by overnight courier. LODA rain collections were vacuum-filtered for spore capture on the same type of cellulose nitrate filter $(0.45-$ $\mu \mathrm{m}$ pore size) in the laboratory, following the methodology described in Barnes et al. (2).

All filters in the United States and Canada were processed and analyzed for the presence of $P$. pachyrhizi DNA using the procedure described in Barnes et al. (2). The procedure does not provide information on spore viability at the time of deposition. Briefly, filters were first sonicated and centrifuged to remove residue, then the DNA was extracted and amplified using a nested quantitative polymerase chain reaction assay (qPCR) with a $P$. pachyrhizi specific Taqman probe. The detection limit on this procedure was one to two spores per sample, which translates into 15 to 30 spores $/ \mathrm{m}^{2}$. A standard curve was created to estimate the number of spores per rain sample by picking individual $P$. pachyrhizi spores and running them through the assay. For this analysis, the spore loads of samples positive for $P$. pachyrhizi were categorized in relative terms as high ( $>430$ spores $/ \mathrm{m}^{2}$ ), moderate (430 to 81 spores $/ \mathrm{m}^{2}$ ), low (80 to 16 spores $\left./ \mathrm{m}^{2}\right)$, and trace $\left(<15\right.$ spores $\left./ \mathrm{m}^{2}\right)$ based on the qPCR values. Both the U.S. and Canadian groups sequenced a subset of amplicons from several positive samples. Consensus sequences were compared to other DNA sequences through BLASTN analysis of sequences available on the GenBank website and previously obtained sequences (2) to further demonstrate that the spores captured in rainwater were $P$. pachyrhizi.

IAMS. The IAMS was used to forecast the geographic spread of SBR in North America from April through December. The model was configured with six modules including spore release and escape from the plant canopy, atmospheric transport, mortality due to exposure to solar radiation, dry and wet deposition of spores, host development at destinations, and disease progress on these hosts. The latter two modules were not used in this study. A full description of the model is provided in Isard et al. (19).

The domain of the model is a polygon extending from 7.5 to $50^{\circ} \mathrm{N}$ latitude and from 60 to $130^{\circ} \mathrm{E}$ longitude with a time step of 1 $\mathrm{h}$. The surface grid resolution of IAMS is approximately $10 \mathrm{~km}$, 
while the vertical resolution is defined by the standard pressure levels $(1,000,950,900,850,800,700,600$, and $500 \mathrm{kPa})$, which gives as many as eight 3-dimensional "atmospheric cells" above each grid cell on the ground. The weather data to drive the simulations are output from U.S. National Oceanic and Atmospheric Administration National Center for Environmental Prediction models and the U.S. National Weather Service Weather Surveillance Radar, 1988, Doppler Stage IV radar precipitation model.

The IAMS relies on host acreage and sentinel plot observations to estimate the spore release rate from source areas in a grid cell. Spore release from an infected soybean or kudzu location is assumed to occur over a 6-h, midday period, and the escape of spores from a canopy is estimated as a function of plant development and surface wind speed. All spores escaping the canopy enter the lowest atmospheric cell above an infected surface grid cell. During subsequent time steps, the spores spread out from the atmospheric cell in an arc centered on the mean wind vector for the hour. Vertical movements of spores among atmospheric cells occur in the direction of the vertical wind vector. The number of spores in each destination atmospheric cell is the sum of the contributions from all other atmospheric cells for the preceding hour interval. Spores are killed following exposure to UV radiation after transport during each time step. Dry deposition occurs when it is not raining and there is downward vertical motion, and wet deposition is estimated as a function of the surface precipitation. For this analysis, wet deposition of viable spores was summed over weekly time periods to correspond with rainwater collection periods. The viable spore deposition output is categorized in relative terms as high $\left(>10^{5}\right.$ spores/ha), moderate $\left(10^{5}\right.$ to $10^{3}$ spores/ha), low $\left(10^{3}\right.$ to $10^{1}$ spores/ha), and trace $\left(<10^{1}\right.$ spores/ha).

\section{Results and Discussion}

Soybean rust spread in 2007. By the end of April 2007, sites with $P$. pachyrhizi infected kudzu in the United States could only be found within the Florida peninsula (36). May was a particularly dry month in the southeast, reinforcing an ongoing drought that continued throughout the summer and kept SBR at low levels east of the Mississippi until late August. In contrast, precipitation was generally above normal in the southwestern portion of the Mississippi River basin during the late spring and early summer. The first report of SBR in Louisiana occurred on 11 May, and a report from eastern Texas soon followed. By the end of July, the disease had been found on soybean throughout eastern Texas, central Louisiana, southwestern Arkansas, and southeastern Oklahoma.

$P$. pachyrhizi was detected in only a few of the rain samples from the United States and Canada during June 2007 (Table 1). In general, the locations from which the samples were positive for $P$. pachyrhizi were dispersed throughout the eastern portion of the

Table 1. Spore concentrations (spores $/ \mathrm{m}^{2}$ ) in rain samples for collection sites in 2007, with dates representing end of weekly collection periods

\begin{tabular}{|c|c|c|c|c|c|c|c|c|c|c|c|c|c|c|c|c|c|}
\hline Station & Lat. & Long. & $\underset{\text { in }}{\Xi}$ & $\underset{\Xi}{\Xi}$ & $\stackrel{\Xi}{\Xi}$ & 塄 & $\underset{m}{\Xi}$ & $\stackrel{\Xi}{\Xi}$ & $\Xi$ & $\underset{\Xi}{\Xi}$ & $\underset{\bar{m}}{\Xi}$ & $\stackrel{n}{2}$ & $\begin{array}{l}\stackrel{\infty}{\Xi} \\
\pm\end{array}$ & 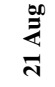 & 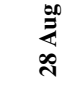 & $\begin{array}{l}\text { षे } \\
\text { षे }\end{array}$ & ڤั \\
\hline Baldwin, AL & 30.7905 & -87.8497 & 0 & 0 & 0 & 0 & 0 & 0 & 0 & 0 & 0 & 0 & 0 & 0 & 0 & 4 & 3 \\
\hline Dallas, AL & 32.4583 & -87.2422 & 0 & 0 & 0 & 0 & 0 & 0 & 0 & 0 & 24 & 0 & 0 & 0 & 0 & 0 & 0 \\
\hline Mobile, AL & 30.4746 & -88.1411 & 0 & 0 & 0 & 0 & 0 & 0 & 0 & 6 & 0 & 14 & 0 & 0 & 10 & 0 & 37 \\
\hline De Kalb, AL & 34.2886 & -85.9699 & 0 & 0 & 67 & 0 & 0 & 0 & 0 & 0 & 0 & 0 & 0 & 0 & 0 & 0 & 0 \\
\hline Bradley, AR & 33.605 & -92.0972 & 0 & 0 & 0 & 0 & 0 & 0 & 0 & 0 & 0 & 0 & 0 & 0 & 0 & 0 & 0 \\
\hline Clark, AR & 34.1795 & -93.0986 & 0 & 19 & 0 & 0 & 0 & 0 & 0 & 0 & 0 & 0 & 0 & 0 & 0 & 0 & 0 \\
\hline Marion, AR & 36.0839 & -92.5869 & 0 & 0 & 0 & 0 & 0 & 0 & 0 & 11 & 0 & 0 & 0 & 0 & 0 & 0 & 0 \\
\hline Washington, AR & 36.1006 & -94.1733 & 0 & 0 & 0 & 21 & 0 & 0 & 30 & 0 & 0 & 0 & 0 & 0 & 0 & 0 & 0 \\
\hline Gadsden, FL & 30.5486 & -84.6004 & 0 & 0 & 0 & 0 & 0 & 0 & 0 & 0 & 0 & 0 & 0 & 0 & 0 & 0 & 0 \\
\hline Liberty, FL & 30.1106 & -84.9902 & 0 & 0 & 0 & 0 & 76 & 0 & 0 & 6 & 0 & 0 & 0 & 4 & 0 & 0 & 0 \\
\hline Charlton, GA & 30.7403 & -82.1286 & 0 & 0 & 0 & 0 & 0 & 0 & 0 & 0 & 0 & 0 & 0 & 177 & 0 & 0 & 0 \\
\hline Evans, GA & 32.1411 & -81.9714 & 0 & 0 & 0 & 0 & 0 & 0 & 0 & 0 & 0 & 0 & 0 & 0 & 0 & 0 & 0 \\
\hline Pike, GA & 33.1778 & -84.4061 & 0 & 0 & 0 & 0 & 0 & 0 & 0 & 0 & 0 & 0 & 0 & 91 & 0 & 0 & 0 \\
\hline Tift, GA & 31.5183 & -83.5483 & 0 & 0 & 0 & 0 & 0 & 0 & 0 & 0 & 0 & 0 & 0 & 0 & 0 & 0 & 0 \\
\hline Clayton, IA & 42.9097 & -91.47 & 0 & 0 & 0 & 0 & 0 & 0 & 0 & 0 & 0 & 0 & 0 & 0 & 243 & 2 & 30 \\
\hline Lucas, IA & 40.9631 & -93.3925 & 0 & 0 & 0 & 0 & 0 & 28 & 0 & 0 & 0 & 0 & 0 & 0 & 22 & 0 & 0 \\
\hline Champaign, IL & 40.0533 & -88.3719 & 0 & 0 & 0 & 0 & 0 & 0 & 0 & 0 & 0 & 0 & 2 & 0 & 16 & 0 & 0 \\
\hline De Kalb, IL & 41.8414 & -88.8511 & 0 & 0 & 0 & 0 & 0 & 0 & 0 & 0 & 0 & 0 & 0 & 125 & 0 & 0 & 0 \\
\hline Madison, IL & 38.8689 & -89.6219 & 0 & 0 & 0 & 0 & 0 & 0 & 0 & 0 & 0 & 0 & 0 & 62 & 0 & 0 & 0 \\
\hline Pope, IL & 37.4356 & -88.6719 & 0 & 0 & 0 & 0 & 0 & 0 & 0 & 0 & 8 & 0 & 0 & 0 & 4 & 0 & 29 \\
\hline Warren, IL & 40.9333 & -90.7231 & 0 & 0 & 0 & 0 & 0 & 0 & 0 & 0 & 0 & 0 & 0 & 95 & 10 & 0 & 0 \\
\hline Huntington, IN & 40.84 & -85.4639 & 0 & 0 & 0 & 0 & 0 & 0 & 0 & 0 & 0 & 0 & 0 & 112 & 0 & 0 & 0 \\
\hline Knox, IN & 38.7408 & -87.4855 & 0 & 0 & 0 & 0 & 35 & 0 & 0 & 0 & 0 & 0 & 0 & 0 & 6 & 0 & 0 \\
\hline Porter, IN & 41.6318 & -87.0881 & 0 & 0 & 0 & 0 & 0 & 0 & 0 & 0 & 0 & 0 & 0 & 0 & 0 & 0 & 0 \\
\hline Tippecanoe, IN & 40.4749 & -86.9924 & 0 & 0 & 0 & 0 & 0 & 21 & 0 & 0 & 36 & 0 & 104 & 0 & 0 & 0 & 0 \\
\hline Crawford, KS & 37.6511 & -94.8036 & 0 & 15 & 0 & 0 & 0 & 0 & 0 & 0 & 11 & 0 & 0 & 87 & 0 & 0 & 0 \\
\hline Riley, KS & 39.1022 & -96.6092 & 0 & 11 & 0 & 0 & 0 & 0 & 0 & 0 & 41 & 0 & 140 & 126 & 0 & 0 & 0 \\
\hline Scott, KS & 38.6717 & -100.9164 & 0 & 0 & 0 & 0 & 0 & 0 & 0 & 53 & 0 & 0 & 0 & 111 & 0 & 0 & 0 \\
\hline Washington, KY & 37.7047 & -85.0489 & 0 & 0 & 0 & 0 & 0 & 0 & 0 & 0 & 62 & 0 & 0 & 0 & 26 & 0 & 0 \\
\hline Rowan, KY & 38.1183 & -83.5469 & 0 & 0 & 0 & 0 & 0 & 0 & 0 & 0 & 0 & 0 & 0 & 0 & 0 & 0 & 44 \\
\hline Trigg, KY & 36.9028 & -88.0119 & 0 & 0 & 0 & 0 & 0 & 0 & 0 & 0 & 0 & 0 & 39 & 0 & 0 & 0 & 0 \\
\hline Iberia, LA & 29.9297 & -91.7153 & 0 & 14 & 0 & 0 & 0 & 0 & 0 & 0 & 0 & 0 & 0 & 0 & 0 & 41 & 0 \\
\hline Washington, LA & 30.8114 & -90.1808 & 0 & 2 & 0 & 0 & 0 & 0 & 0 & 0 & 0 & 0 & 0 & 0 & 0 & 0 & 34 \\
\hline Kalamazoo, MI & 42.4103 & -85.3928 & 0 & 0 & 0 & 0 & 0 & 0 & 0 & 0 & 42 & 0 & 0 & 133 & 0 & 0 & 20 \\
\hline Washtenaw, MI & 42.4164 & -83.9019 & 0 & 0 & 0 & 0 & 0 & 0 & 0 & 0 & 0 & 45 & 0 & 0 & 0 & 0 & 0 \\
\hline Anoka, MN & 45.4017 & -93.2031 & 0 & 0 & 0 & 0 & 0 & 0 & 0 & 0 & 0 & 0 & 0 & 0 & 0 & 0 & 0 \\
\hline Morrison, MN & 46.2494 & -94.4972 & 0 & 0 & 0 & 0 & 0 & 0 & 0 & 0 & 0 & 0 & 0 & 0 & 0 & 0 & 0 \\
\hline Redwood, MN & 44.2369 & -95.301 & 0 & 9 & 0 & 0 & 0 & 0 & 0 & 0 & 0 & 0 & 0 & 0 & 0 & 0 & 0 \\
\hline Boone, MO & 38.7536 & -92.1989 & 0 & 0 & 0 & 0 & 0 & 0 & 0 & 0 & 0 & 0 & 0 & 0 & 0 & 0 & 0 \\
\hline Butler, MO & 36.9108 & -90.3186 & 0 & 0 & 0 & 0 & 0 & 0 & 0 & 0 & 0 & 31 & 0 & 0 & 0 & 0 & 0 \\
\hline St. Louis, MO & 38.5208 & -90.5541 & 0 & 0 & 0 & 0 & 0 & 0 & 0 & 0 & 0 & 0 & 0 & 66 & 0 & 0 & 0 \\
\hline Hinds, MS & 32.3069 & -90.3186 & 0 & 0 & 0 & 0 & 0 & 0 & 0 & 0 & 0 & 0 & 0 & 0 & 0 & 0 & 0 \\
\hline Newton, MS & 32.3269 & -89.2086 & 0 & 0 & 0 & 0 & 0 & 0 & 0 & 0 & 0 & 0 & 0 & 0 & 0 & 0 & 0 \\
\hline
\end{tabular}


continent and the spore loads in the positive samples were low and trace levels $\left(<80\right.$ spores $\left./ \mathrm{m}^{2}\right)$. A notable exception was a collection during the week of 6 to 12 June from the coastal region of South Carolina with an estimated spore load of $600 \mathrm{spores} / \mathrm{m}^{2}$. The IAMS simulations for the 2-month period also indicated very low potential for long-distance SBR spread into the continental interior of North America.

The first period in 2007 with spatially clumped P. pachyrhizi spore loads occurred in early July. Three collectors in Ohio and one each in Indiana, Iowa, southern Ontario, and Saskatchewan had positive samples during the first full week of the month, while seven samples from southern Ontario and one each from Ohio and Saskatchewan were positive for $P$. pachyrhizi the following week. All these samples were low and trace levels. IAMS predictions for the corresponding period included relatively heavy deposition of viable spores within the Mississippi River valley in eastern Arkansas, northwestern Mississippi, and extreme western Tennessee to the south of where P. pachyrhizi positive samples were observed. This event was followed by a drought that developed in a large area centered on the Indiana-Ohio border. Only a few of the rain samples over the next month tested positive for P. pachyrhizi. These samples had low and trace spore loads and were dispersed over eastern North America. The IAMS simulations for the corresponding weeks indicated a very low risk of SBR spread beyond the infected region of eastern Texas, central Louisiana, southwestern Arkansas, and southeastern Oklahoma.

The situation changed dramatically during the second week of August. By this time, SBR had been found in 42 counties in Texas, Oklahoma, and Louisiana, providing an ample source for SBR inoculum for long-distance transport. On 8 and 9 August, a middle latitude storm system traversed the High Plains advecting warm moist air and $P$. pachyrhizi urediniospores from the infected counties. The storm system caused heavy precipitation in a broad belt including Nebraska, Kansas, Iowa, Missouri, Illinois, Indiana, and states further east. Both the IAMS output and rain collections for the 8 to 14 August 2007 period indicated wet deposition of spores in the Midwest states and Canada (Fig. 1A). On 16 August, Tropical Storm Erin made landfall near Lamar, TX. During the subsequent 4 days, the storm system moved slowly in a broad arc, first northwest, then north, then northeast across Texas, and into Oklahoma, traversing more than 20 counties with fields infected with SBR. Over the same period, a middle latitude storm system swept across the northern Plains and Great Lake regions, dumping copious amounts of precipitation from the Dakotas, through Minnesota, Iowa, Wisconsin, Illinois, Indiana, Michigan, Ohio, and Ontario. IAMS output for the period indicated spore transport from the infected fields in the southern Plains with moderate levels (430-81 spores $/ \mathrm{m}^{2}$ ) of deposition of viable spores in Kansas, Missouri,

Table 1. (continued from previous page)

\begin{tabular}{|c|c|c|c|c|c|c|c|c|c|c|c|c|c|c|c|c|c|}
\hline Station & Lat. & Long. & $\underset{\text { in }}{\Xi}$ & $\underset{\Xi}{\Xi}$ & $\stackrel{\Xi}{\Xi}$ & 志 & $\underset{m}{\Xi}$ & $\stackrel{\Xi}{\Xi}$ & $\Xi$ & $\frac{\Xi}{\Xi}$ & $\frac{\Xi}{\bar{m}}$ & $\sum_{n}^{e 0}$ & $\begin{array}{l}\stackrel{00}{\Xi} \\
\pm \\
\Xi\end{array}$ & $\frac{00}{\Xi}$ & 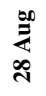 & $\begin{array}{l}\text { के } \\
\text { के }\end{array}$ & ڤัँ \\
\hline Yalobusha, MS & 34.0025 & -89.7993 & 0 & 0 & 0 & 0 & 0 & 0 & 0 & 0 & 0 & 0 & 0 & 0 & 0 & 0 & 0 \\
\hline Bertie, NC & 36.1325 & -77.1708 & 0 & 0 & 0 & 0 & 0 & 0 & 0 & 0 & 0 & 0 & 0 & 0 & 0 & 0 & 0 \\
\hline Carteret, NC & 34.8846 & -76.6207 & 0 & 0 & 0 & 0 & 0 & 0 & 0 & 0 & 0 & 0 & 0 & 0 & 0 & 0 & 0 \\
\hline Rowan, NC & 35.697 & -80.6225 & 0 & 0 & 0 & 59 & 0 & 0 & 0 & 0 & 0 & 0 & 0 & 0 & 0 & 0 & 0 \\
\hline Sampson, NC & 35.0258 & -78.2783 & 0 & 0 & 0 & 0 & 119 & 42 & 0 & 0 & 0 & 0 & 0 & 0 & 0 & 0 & 0 \\
\hline Stutsman, ND & 47.1247 & -99.2381 & 0 & 0 & 0 & 0 & 0 & 0 & 0 & 2 & 0 & 0 & 0 & 0 & 0 & 0 & 0 \\
\hline Saunders, NE & 41.1528 & -96.4912 & 0 & 0 & 0 & 0 & 0 & 0 & 0 & 0 & 0 & 0 & 0 & 0 & 0 & 0 & 0 \\
\hline Lincoln, NE & 41.0592 & -100.7464 & 0 & 60 & 0 & 0 & 0 & 0 & 0 & 0 & 0 & 0 & 0 & 0 & 0 & 0 & 0 \\
\hline Butler, $\mathrm{OH}$ & 39.5314 & -84.7242 & 0 & 0 & 0 & 0 & 0 & 0 & 3 & 0 & 0 & 0 & 0 & 0 & 0 & 0 & 0 \\
\hline Crawford, $\mathrm{OH}$ & 40.917 & -82.9981 & 0 & 0 & 0 & 0 & 0 & 0 & 0 & 0 & 0 & 0 & 0 & 0 & 0 & 0 & 0 \\
\hline Delaware, $\mathrm{OH}$ & 40.3553 & -83.0661 & 0 & 0 & 0 & 0 & 0 & 186 & 0 & 63 & 0 & 0 & 0 & 0 & 0 & 0 & 0 \\
\hline Noble, $\mathrm{OH}$ & 39.7928 & -81.5311 & 0 & 0 & 0 & 0 & 0 & 53 & 0 & 0 & 0 & 0 & 0 & 0 & 0 & 0 & 0 \\
\hline Pickaway, $\mathrm{OH}$ & 39.6358 & -83.26 & 0 & 0 & 0 & 0 & 0 & 33 & 0 & 0 & 0 & 0 & 0 & 0 & 0 & 0 & 0 \\
\hline Wayne, $\mathrm{OH}$ & 40.7822 & -81.92 & 0 & 0 & 0 & 0 & 0 & 0 & 0 & 0 & 0 & 0 & 0 & 0 & 0 & 0 & 0 \\
\hline Alfalfa, OK & 36.8053 & -98.2006 & 62 & 0 & 0 & 0 & 0 & 0 & 0 & 0 & 0 & 0 & 0 & 0 & 0 & 0 & 0 \\
\hline McClain, OK & 34.98 & -97.5214 & 0 & 0 & 0 & 0 & 0 & 0 & 0 & 0 & 0 & 0 & 0 & 0 & 0 & 0 & 0 \\
\hline Centre, PA & 40.7883 & -77.9458 & 41 & 0 & 0 & 0 & 0 & 0 & 0 & 0 & 0 & 0 & 0 & 0 & 0 & 39 & 0 \\
\hline Charleston, SC & 32.9419 & -79.6591 & 0 & 578 & 0 & 0 & 0 & 0 & 0 & 0 & 0 & 0 & 0 & 0 & 0 & 0 & 0 \\
\hline Clarendon, SC & 33.5394 & -80.435 & 0 & 0 & 0 & 0 & 0 & 0 & 0 & 0 & 0 & 0 & 0 & 0 & 0 & 0 & 0 \\
\hline Colleton, SC & 32.5993 & -80.4554 & 0 & 0 & 0 & 0 & 0 & 0 & 0 & 0 & 0 & 0 & 0 & 0 & 0 & 0 & 0 \\
\hline Jackson, SD & 43.9461 & -101.8552 & 0 & 0 & 0 & 0 & 0 & 0 & 0 & 0 & 0 & 0 & 0 & 50 & 0 & 0 & 0 \\
\hline Beadle, SD & 44.355 & -98.2917 & 0 & 0 & 0 & 0 & 0 & 0 & 0 & 0 & 0 & 0 & 0 & 0 & 0 & 0 & 0 \\
\hline Anderson, TN & 35.9614 & -84.2872 & 34 & 0 & 0 & 0 & 0 & 0 & 0 & 0 & 0 & 0 & 0 & 0 & 0 & 0 & 0 \\
\hline Haywood, TN & 35.4678 & -89.1586 & 0 & 0 & 0 & 0 & 0 & 40 & 0 & 0 & 0 & 0 & 0 & 0 & 0 & 0 & 0 \\
\hline Colorado, TX & 29.6614 & -96.2594 & 0 & 0 & 0 & 0 & 0 & 0 & 0 & 0 & 0 & 0 & 0 & 0 & 2 & 0 & 4 \\
\hline Edwards, TX & 30.2614 & -100.555 & 0 & 0 & 0 & 35 & 0 & 0 & 0 & 0 & 0 & 0 & 0 & 0 & 0 & 0 & 0 \\
\hline Culberson, TX & 31.9083 & -104.8028 & 0 & 0 & 0 & 0 & 0 & 0 & 0 & 0 & 0 & 0 & 0 & 6 & 0 & 116 & 0 \\
\hline Albemarle, VA & 38.0402 & -78.5427 & 0 & 0 & 0 & 0 & 0 & 0 & 0 & 0 & 0 & 0 & 0 & 0 & 0 & 93 & 0 \\
\hline Giles, VA & 37.3294 & -80.5579 & 56 & 0 & 0 & 0 & 0 & 0 & 0 & 0 & 0 & 0 & 0 & 41 & 0 & 0 & 0 \\
\hline Taylor, WI & 45.2064 & -90.5978 & 0 & 0 & 0 & 0 & 25 & 0 & 0 & 0 & 0 & 0 & 0 & 51 & 0 & 0 & 0 \\
\hline Vernon, WI & 43.7023 & -90.5685 & 0 & 0 & 0 & 0 & 0 & 0 & 0 & 0 & 0 & 0 & 0 & 31 & 0 & 205 & 0 \\
\hline Walworth, WI & 42.5792 & -88.5006 & 0 & 0 & 0 & 0 & 0 & 0 & 0 & 0 & 0 & 0 & 0 & 0 & 0 & 0 & 0 \\
\hline Morden, MB & 49.18753 & -98.08378 & 0 & 0 & 0 & 0 & 0 & 0 & 0 & 0 & 0 & 0 & 0 & 18 & 0 & 0 & 0 \\
\hline Caledonia, ON & 43.09481 & -79.96121 & 0 & 0 & 0 & 0 & 0 & 0 & 0 & 0 & 0 & 0 & 1 & 1 & 0 & 0 & 0 \\
\hline Forest, ON & 43.05424 & -82.06309 & 0 & 0 & 0 & 0 & 0 & 0 & 0 & 0 & 0 & 0 & 0 & 8 & 0 & 0 & 0 \\
\hline Harrow, ON & 42.03286 & -82.89633 & 0 & 0 & 0 & 0 & 0 & 0 & 0 & 0 & 0 & 0 & 0 & 222 & 0 & 0 & 0 \\
\hline Kemptville, ON & 45.01581 & -75.64549 & 0 & 0 & 0 & 0 & 0 & 0 & 12 & 0 & 0 & 0 & 0 & 0 & 0 & 0 & 0 \\
\hline Morrisburg, ON & 44.89972 & -75.18709 & 0 & 0 & 0 & 0 & 0 & 0 & 3 & 0 & 0 & 0 & 0 & 6 & 0 & 0 & 0 \\
\hline Ottawa, ON & 45.39 & -75.719 & 0 & 0 & 0 & 0 & 0 & 0 & 16 & 0 & 0 & 2 & 0 & 116 & 0 & 0 & 0 \\
\hline Ridgetown, ON & 42.45587 & -81.88235 & 0 & 0 & 0 & 0 & 0 & 0 & 16 & 0 & 0 & 0 & 3 & 0 & 0 & 0 & 0 \\
\hline St. Thomas, ON & 42.81384 & -81.12051 & 0 & 0 & 3 & 0 & 0 & 17 & 31 & 0 & 0 & 0 & 0 & 0 & 23 & 0 & 0 \\
\hline Toronto, ON & 43.66129 & -79.40128 & 0 & 0 & 0 & 0 & 0 & 0 & 15 & 0 & 0 & 0 & 0 & 40 & 0 & 7 & 0 \\
\hline Woodslee, ON & 42.21182 & -82.74671 & 0 & 0 & 0 & 0 & 0 & 0 & 10 & 0 & 0 & 1 & 0 & 0 & 0 & 0 & 0 \\
\hline Saskatoon, SK & 52.11667 & -106.6333 & 0 & 0 & 0 & 0 & 0 & 20 & 11 & 0 & 0 & 0 & 0 & 10 & 0 & 0 & 0 \\
\hline
\end{tabular}




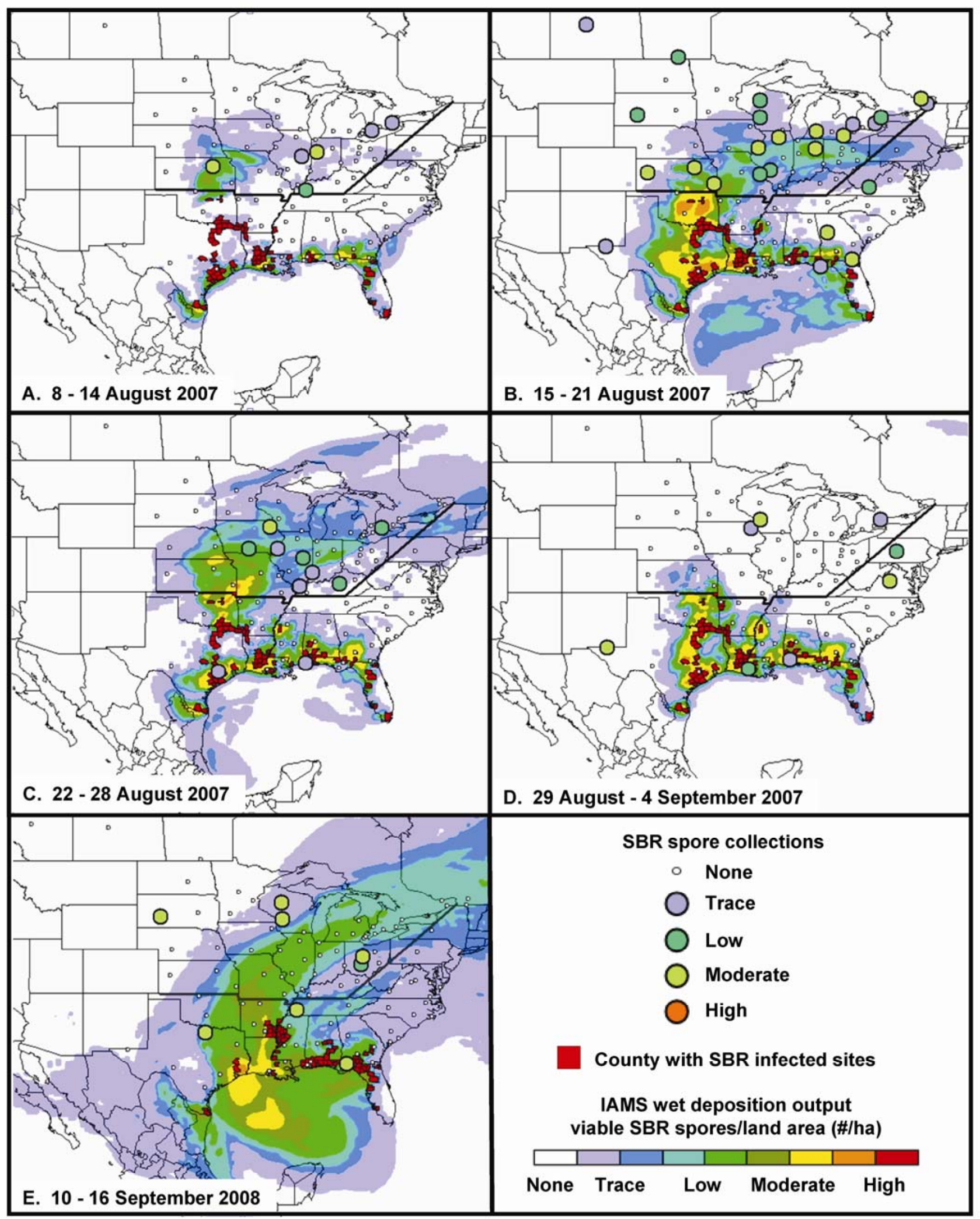

Fig. 1. Maps showing 2007 and 2008 study weeks for which rain samples and Integrated Aerobiology Modeling System (IAMS) output both indicate deposition of Phakopsora pachyrhizi urediniospores in the continental interior of North America (A, 8-14 August 2007; B, 15-21 August 2007; C, 22-28 August 2007 ; D, 29 August-4 September 2007; and E, 10-16 September 2008). The area to the north of the heavy line demarcating the southern borders of Kansas, Missouri, and Kentucky and between the Appalachian and Rocky mountains represents the continental interior of North America for the purposes of this study. Spore load estimates from rain samples are categorized in relative terms as high $\left(>430 \mathrm{spores} / \mathrm{m}^{2}\right)$, moderate $\left(430\right.$ to $\left.81 \mathrm{spores} / \mathrm{m}^{2}\right)$, low $\left(80\right.$ to $\left.16 \mathrm{spores} / \mathrm{m}^{2}\right)$, and trace $\left(<15 \mathrm{spores} / \mathrm{m}^{2}\right)$, and IAMS viable spore deposition output is

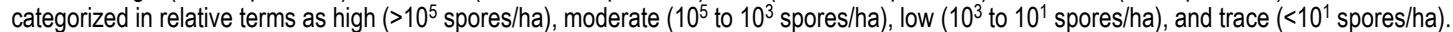


southern Iowa, Illinois, Indiana, and western Ohio (Fig. 1B). Higher P. pachyrhizi spore loads were identified in the rain samples from the continental interior of North America during 15 to 21 August 2007 than during any other sampling period in the 2-year study. $P$. pachyrhizi spore loads were moderate in 11 samples from locations in Kansas, Illinois, Indiana, Michigan, and Ontario, and low or trace in samples from seven locations in Saskatchewan, Manitoba, South Dakota, Missouri, Illinois, Wisconsin, and Ontario.

In the week following Tropical Storm Erin, a strong low-pressure system became established over the Great Lakes with strong winds blowing from northern Texas and Oklahoma toward the lakes. Again, the IAMS output indicated transport and moderate levels of deposition of viable $P$. pachyrhizi spores in eastern Kansas and Nebraska, Missouri, southern Iowa, and Indiana (Fig. 1C). During this week, two rain samples from Iowa, three from Illinois, and one each from Kentucky, Indiana, and southern Ontario were positive for P. pachyrhizi.

A series of cold fronts associated with strong air flows from the south traversed the continental interior of North America during September. Both the IAMS and the spore collections indicated moderate levels of deposition of SBR spores in small regions of the continental interior for the 29 August - 04 September period (Fig. 1D). IAMS output indicated stronger potential for spore transport from the infected regions northward during most of the remaining weeks in the month. Spore sampling from the rain collection network ceased after the second week of September 2007, and a few widely dispersed locations received low levels of $P$. pachyrhizi spores in the final sampling period.

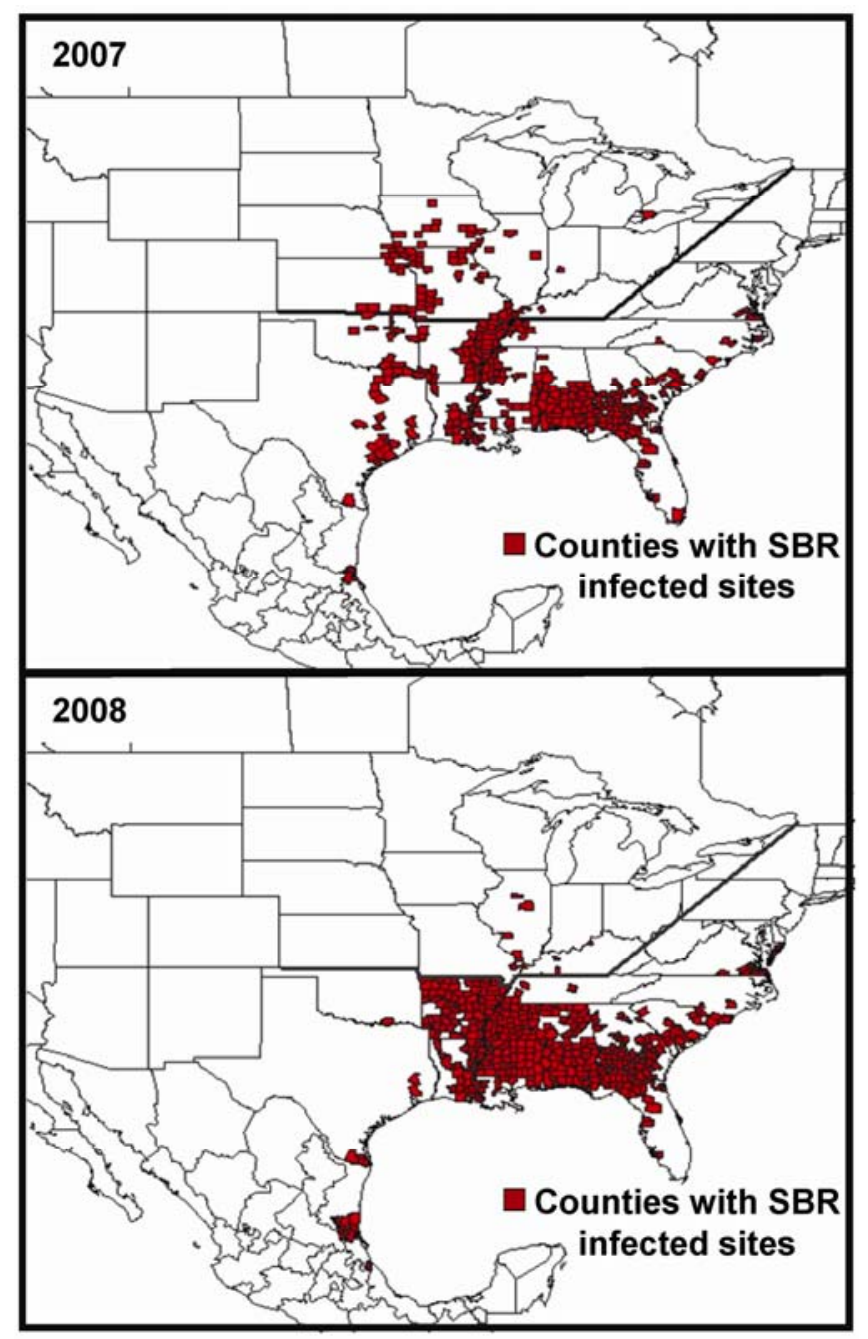

Fig. 2. Geographic distribution of U.S. and Canadian counties and Mexican municipalities for which soybean rust infections were reported in 2007 and 2008.
The first reports of rust symptoms on soybean in the continental interior in 2007 came from Kentucky and Nebraska on 21 September, 5 to 6 weeks after both the rain collections and IAMS predictions indicated substantial incursions of $P$. pachyrhizi urediniospores into the region. Reports from Illinois and Missouri followed in the same week. By the end of September, soybeans throughout the northern states had begun to senesce, and sentinel plot monitoring had for the most part been discontinued. However, over the next month, SBR was found in Iowa, Nebraska, Indiana, and as far north and east as southern Ontario. Overall, SBR was reported in 355 U.S., 1 Canadian, and 2 Mexican counties or municipalities in 2007, 72 of which were in the continental interior of North America (Fig. 2), with the vast majority of the observations in August, September, and October (Fig. 3).

Soybean rust spread in 2008. The spread of SBR in the southern United States occurred more slowly in 2008 than during the previous year. By mid-April, locations with $P$. pachyrhizi infected kudzu in the United States could only be found within the Florida peninsula (36). The disappearance of SBR from the winter monitoring sites in coastal Louisiana and eastern Texas may have been due to a cold outbreak in mid-April coupled with dry conditions west of the Mississippi River. The drought from the previous year continued throughout the spring and summer months in much of Alabama, Georgia, and southern Mississippi. The first report of $P$. pachyrhizi on kudzu occurred in Texas on 19 April and in Louisiana on 27 May. However, the next report from west of the Mississippi River did not occur until 28 July, when rust was found in the Rio Grande Valley on soybean. During January and February, SBR had been found at three locations in Mexico but was no longer present at the beginning of June. By the end of July, outside of the state of Florida, SBR was only known to be present in three counties west of the Mississippi River, one county in extreme southern Georgia, and in two counties along the Alabama coast.

P. pachyrhizi was detected in low to trace spore loads $(<80$ spores $/ \mathrm{m}^{2}$ ) and in widely dispersed rain samples from the United States and Canada during May through August 2008 (Table 2). Notable exceptions occurred during the last week in June and the first week in July, when strong cold fronts traversed the Great Lakes region, advecting warm moist air and $P$. pachyrhizi spores northward from the southern United States. During the last week in June, 15 collection sites in Alberta, South Dakota, Kansas, Illinois, Wisconsin, Ohio, and Ontario recorded low and trace spore loads. Rain samples the following week from 14 locations in the Sas-

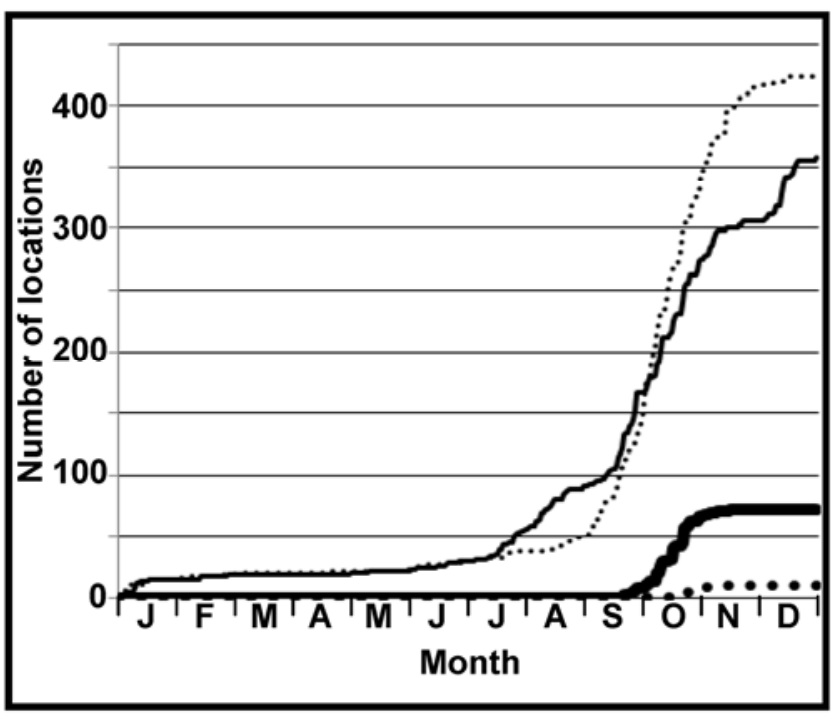

Fig. 3. Temporal progression of soybean rust spread in U.S. and Canadian counties and Mexican municipalities for 2007 and 2008. The thin and thick solid lines represent 2007 samples from all sites and only continental interior locations, respectively. The lines composed of small and large dots represent 2008 samples from all sites and only continental interior locations, respectively. 
katchewan, Manitoba, Kansas, Minnesota, Illinois, Kentucky, and southern Ontario contained low and trace levels of $P$. pachyrhizi urediniospores. The IAMS predicted only low levels of SBR spore deposition in the continental interior during this period.

Tropical Storm Fay brought abundant rainfall to the southeastern United States during late August 2008, with as much as 10 to 25 $\mathrm{cm}$ more precipitation than normal for the month. By early September, SBR had been reported in the Delta region of Mississippi and Arkansas. On 1 September, Hurricane Gustov made landfall in Louisiana. Although the system downgraded rapidly, the center of the low moved slowly up the Mississippi River Valley over the subsequent 5 days. In the upper Mississippi River Valley, the tropical low merged with a middle latitude storm system to produce copious amounts of precipitation across eastern Iowa, Missouri, Illinois, Indiana, and Michigan. Moderate levels (430 to 81 spores $/ \mathrm{m}^{2}$ ) of $P$. pachyrhizi urediniospores were reported for three rainwater collectors in Illinois and Indiana, while a sample from Wisconsin had a low level of spores during 03 to 09 September. Over the next 2 weeks, SBR continued to be found in additional counties in the Delta region and was also identified in northern
Alabama, central Georgia, and throughout South Carolina. On 13 September, Hurricane Ike made landfall in eastern Texas. This system weakened rapidly and over the next 2 days moved quickly up the Mississippi River Valley and across the Great Lakes. Moderate $P$. pachyrhizi spore loads were detected in the 10 to 16 September rain samples from one location in western South Dakota, two in Wisconsin, and one in Ohio (Fig. 1E), while low levels of SBR spores were detected from a second site in Ohio. IAMS predicted moderate levels of $P$. pachyrhizi spore deposition in the upper Mississippi River Valley for this period as well.

The first report of SBR symptoms on soybean in the continental interior in 2008 came from Kentucky on 16 October and was soon followed by reports from Illinois. As in 2007, 5 to 6 weeks elapsed between the period when both the rain samples and IAMS simulations indicated $P$. pachyrhizi urediniospore deposition and SBR was reported in the continental interior region. Monitoring had generally ceased by the end of the month in the region, by which date SBR had been reported in 10 counties from 3 states within the continental interior. In 2008, SBR was observed in 409 counties in the United States and 15 municipalities in Mexico, with no reports

Table 2. Spore concentrations $\left(\right.$ spores $/ \mathrm{m}^{2}$ ) in rain samples for collection sites in 2008 , with dates representing end of weekly collection periods and dashes indicating that no measurement is available

\begin{tabular}{|c|c|c|c|c|c|c|c|c|c|c|c|c|c|c|c|c|c|c|c|c|c|}
\hline Station & Lat. & Long. & $\underset{\Xi}{\Xi}$ & 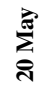 & 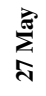 & $\underset{m}{\Xi}$ & $\stackrel{\Xi}{\Xi}$ & $\Xi$ & $\underset{\Xi}{\Xi}$ & $\Xi$ & $\underset{\infty}{\Xi}$ & $\begin{array}{l}\Xi \\
\cong\end{array}$ & 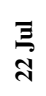 & $\frac{\Xi}{3}$ & $\sum_{10}^{\infty}$ & $\begin{array}{l}\stackrel{00}{E} \\
\stackrel{U}{U}\end{array}$ & $\begin{array}{l}\stackrel{60}{E} \\
2\end{array}$ & \begin{tabular}{l} 
No \\
\multirow{2}{*}{}
\end{tabular} & $\begin{array}{l}\text { จे } \\
\text { v }\end{array}$ & $\begin{array}{l}\text { จें } \\
\text { ڤ్ } \\
\text { a }\end{array}$ & 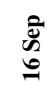 \\
\hline Baldwin, AL & 30.7905 & -87.8497 & 0 & 0 & 15 & 0 & 0 & 0 & 0 & 0 & 0 & 0 & 0 & 0 & 0 & 0 & 0 & 127 & 0 & 0 & 0 \\
\hline De Kalb, AL & 34.2886 & -85.9699 & 0 & 0 & 0 & 0 & 0 & 0 & 0 & 0 & 10 & 0 & 0 & 0 & 0 & 0 & 0 & 0 & 0 & 0 & 0 \\
\hline Dallas, AL & 32.4583 & -87.2422 & 0 & 0 & 0 & 0 & 0 & 12 & 0 & 0 & 0 & 0 & 0 & 0 & 0 & 0 & 63 & 0 & 0 & 0 & 0 \\
\hline Mobile, AL & 30.4746 & -88.1411 & 0 & 0 & 0 & 0 & 0 & 0 & 0 & 0 & 0 & 0 & 0 & 0 & 0 & 0 & 0 & 0 & 0 & 0 & 0 \\
\hline Bradley, AR & 33.6050 & -92.0972 & 0 & 0 & 0 & 0 & 0 & 0 & 0 & 0 & 0 & 0 & 0 & 0 & 0 & 0 & 0 & 0 & 0 & 0 & 0 \\
\hline Clark, AR & 34.1795 & -93.0986 & 0 & 0 & 0 & 0 & 0 & 0 & 0 & 0 & 0 & 0 & 0 & 0 & 0 & 0 & 0 & 0 & 0 & 0 & 0 \\
\hline Marion, AR & 36.0839 & -92.5869 & 17 & 0 & 0 & 0 & 0 & 0 & 0 & 0 & 0 & 0 & 0 & 0 & 0 & 0 & 0 & 0 & 0 & 0 & 0 \\
\hline Washington, AR & 36.1006 & -94.1733 & 0 & 7 & 0 & 0 & 0 & 0 & 0 & 0 & 0 & 0 & 0 & 0 & 0 & 0 & 40 & 0 & 0 & 0 & 0 \\
\hline Gadsden, FL & 30.5486 & -84.6004 & 0 & 0 & 0 & 0 & 0 & 0 & 0 & 0 & 0 & 0 & 6 & 0 & 0 & 0 & 0 & 2 & 233 & 70 & 121 \\
\hline Liberty, FL & 30.1106 & -84.9902 & 0 & 0 & 0 & 0 & 0 & 0 & 0 & 0 & 0 & 0 & 0 & 0 & 0 & 0 & 0 & 0 & 0 & 0 & 0 \\
\hline Charlton, GA & 30.7403 & -82.1286 & 0 & 0 & 0 & 0 & 0 & 0 & 139 & 0 & 0 & 0 & 0 & 0 & 0 & 0 & 0 & 0 & 0 & 205 & 0 \\
\hline Evans, GA & 32.1411 & -81.9714 & 0 & 0 & 0 & 0 & 0 & 0 & 0 & 0 & 0 & 0 & 0 & 0 & 0 & 0 & 0 & 0 & 0 & 0 & 0 \\
\hline Pike, GA & 33.1778 & -84.4061 & 0 & 0 & 0 & 0 & 0 & 0 & 0 & 0 & 0 & 0 & 0 & 0 & 0 & 0 & 7 & 0 & 47 & 233 & 0 \\
\hline Tift, GA & 31.5183 & -83.5483 & 0 & 0 & 0 & 0 & 0 & 0 & 0 & 0 & 0 & 0 & 0 & 0 & 0 & 0 & 0 & 0 & 0 & 0 & 0 \\
\hline Clayton, IA & 42.9097 & -91.4700 & 0 & 0 & 0 & 0 & 0 & 0 & 0 & 0 & 0 & 0 & 0 & 0 & 0 & 0 & 0 & 0 & 0 & 0 & 0 \\
\hline Lucas, IA & 40.9631 & -93.3925 & 0 & 0 & 0 & 0 & 23 & 0 & 0 & 0 & 0 & 0 & 0 & 0 & 0 & 0 & 0 & 0 & 0 & 0 & 0 \\
\hline Champaign, IL & 40.0533 & -88.3719 & 0 & 0 & 0 & 0 & 0 & 0 & 0 & 21 & 36 & 0 & 0 & 0 & 0 & 0 & 0 & 0 & 0 & 0 & 0 \\
\hline De Kalb, IL & 41.8414 & -88.8511 & 0 & 0 & 0 & 0 & 0 & 0 & 0 & 20 & 0 & 0 & 0 & 0 & 0 & 0 & 0 & 0 & 0 & 0 & 0 \\
\hline Madison, IL & 38.8689 & -89.6219 & 0 & 0 & 0 & 0 & 0 & 0 & 0 & 45 & 0 & 0 & 0 & 0 & 0 & 0 & 0 & 0 & 0 & 0 & 0 \\
\hline Pope, IL & 37.4356 & -88.6719 & 0 & 0 & 10 & 0 & 0 & 0 & 0 & 43 & 0 & 0 & 0 & 0 & 0 & 0 & 0 & 0 & 0 & 0 & 0 \\
\hline Warren, IL & 40.9333 & -90.7231 & 0 & 0 & 0 & 0 & 0 & 0 & 0 & 48 & 20 & 0 & 16 & 0 & 0 & 0 & 0 & 0 & 0 & 102 & 0 \\
\hline Huntington, IN & 40.8400 & -85.4639 & 0 & 0 & 0 & 0 & 0 & 0 & 0 & 0 & 0 & 0 & 0 & 0 & 0 & 0 & 0 & 0 & 0 & 0 & 0 \\
\hline Knox, IN & 38.7408 & -87.4855 & 0 & 0 & 0 & 0 & 0 & 0 & 0 & 0 & 0 & 0 & 0 & 0 & 0 & 0 & 0 & 0 & 0 & 0 & 0 \\
\hline Porter, IN & 41.6318 & -87.0881 & 0 & 0 & 0 & 0 & 0 & 0 & 0 & 0 & 0 & 0 & 0 & 0 & 0 & 0 & 0 & 0 & 0 & 128 & 0 \\
\hline Tippecanoe, IN & 40.4749 & -86.9924 & 0 & 0 & 0 & 0 & 0 & 0 & 0 & 0 & 0 & 0 & 0 & 0 & 0 & 0 & 0 & 0 & 0 & 84 & 0 \\
\hline Crawford, KS & 37.6511 & -94.8036 & 0 & 0 & 0 & 0 & 0 & 0 & 0 & 0 & 0 & 0 & 0 & 0 & 0 & 0 & 0 & 0 & 0 & 0 & 0 \\
\hline Riley, KS & 39.1022 & -96.6092 & 0 & 0 & 0 & 0 & 0 & 0 & 0 & 4 & 0 & 0 & 0 & 0 & 0 & 0 & 0 & 0 & 0 & 0 & 0 \\
\hline Scott, KS & 38.6717 & -100.9164 & 0 & 0 & 0 & 0 & 0 & 0 & 0 & 0 & 13 & 0 & 0 & 0 & 0 & 0 & 0 & 0 & 0 & 0 & 0 \\
\hline Rowan, KY & 38.1183 & -83.5469 & 0 & 0 & 0 & 0 & 15 & 0 & 0 & 0 & 15 & 0 & 0 & 0 & 0 & 0 & 0 & 0 & 0 & 0 & 0 \\
\hline Trigg, KY & 36.9028 & -88.0119 & 0 & 17 & 0 & 0 & 24 & 0 & 0 & 0 & 0 & 0 & 0 & 0 & 0 & 0 & 0 & 0 & 0 & 0 & 0 \\
\hline Washington, KY & 37.7047 & -85.0489 & 0 & 0 & 0 & 0 & 0 & 0 & 0 & 0 & 16 & 0 & 0 & 0 & 0 & 0 & 0 & 0 & 0 & 0 & 0 \\
\hline Iberia, LA & 29.9297 & -91.7153 & 0 & 0 & 0 & 0 & 43 & 0 & 0 & 68 & 28 & 0 & 0 & 0 & 0 & 0 & 0 & 0 & 0 & 0 & 0 \\
\hline Washington, LA & 30.8114 & -90.1808 & 0 & 0 & 0 & 0 & 0 & 0 & 0 & 0 & 34 & 0 & 0 & 0 & 0 & 0 & 0 & 0 & 0 & 0 & 0 \\
\hline Kalamazoo, MI & 42.4103 & -85.3928 & 0 & 0 & 0 & 0 & 0 & 0 & 0 & 0 & 0 & 0 & 0 & 0 & 0 & 0 & 0 & 0 & 0 & 0 & 0 \\
\hline Tuscola, MI & 43.6131 & -83.3581 & 0 & 0 & 0 & 0 & 0 & 0 & 0 & 0 & 0 & 0 & 0 & 0 & 0 & 0 & 0 & 0 & 0 & 0 & 0 \\
\hline Washtenaw, MI & 42.4164 & -83.9019 & 0 & 0 & 0 & 0 & 0 & 0 & 0 & 0 & 0 & 0 & 0 & 0 & 0 & 0 & 0 & 0 & 0 & 0 & 0 \\
\hline Anoka, MN & 45.4017 & -93.2031 & 0 & 0 & 0 & 0 & 0 & 0 & 23 & 0 & 0 & 0 & 0 & 0 & 0 & 0 & 43 & 0 & 0 & 0 & 0 \\
\hline Morrison, $\mathrm{MN}$ & 46.2494 & -94.4972 & 0 & 0 & 0 & 0 & 0 & 0 & 0 & 0 & 39 & 0 & 0 & 0 & 0 & 0 & 0 & 0 & 0 & 0 & 0 \\
\hline Redwood, MN & 44.2369 & -95.3010 & 0 & 0 & 0 & 16 & 24 & 0 & 0 & 0 & 0 & 0 & 0 & 0 & 0 & 0 & 0 & 0 & 0 & 0 & 0 \\
\hline Boone, MO & 38.7536 & -92.1989 & 0 & 0 & 0 & 0 & 0 & 0 & 0 & 0 & 0 & 0 & 16 & 0 & 0 & 0 & 0 & 0 & 0 & 0 & 0 \\
\hline Butler, MO & 36.9108 & -90.3186 & 0 & 0 & 0 & 4 & 0 & 0 & 0 & 0 & 0 & 0 & 0 & 0 & 0 & 0 & 0 & 0 & 0 & 0 & 0 \\
\hline St. Louis, MO & 38.5208 & -90.5541 & 0 & 0 & 0 & 0 & 0 & 0 & 0 & 0 & 0 & 0 & 0 & 0 & 0 & 0 & 0 & 0 & 0 & 0 & 0 \\
\hline Hinds, MS & 32.3069 & -90.3186 & 0 & 0 & 0 & 0 & 0 & 0 & 0 & 0 & 0 & 0 & 0 & 0 & 0 & 0 & 0 & 0 & 0 & 0 & 0 \\
\hline Newton, MS & 32.3269 & -89.2086 & 0 & 0 & 20 & 0 & 0 & 0 & 0 & 0 & 0 & 0 & 0 & 0 & 0 & 0 & 30 & 0 & 0 & 0 & 0 \\
\hline Yalobusha, MS & 34.0025 & -89.7993 & 0 & 0 & 0 & 0 & 0 & 0 & 0 & 0 & 48 & 0 & 0 & 0 & 0 & 0 & 0 & 0 & 0 & 41 & 0 \\
\hline Bertie, NC & 36.1325 & -77.1708 & 0 & 0 & 0 & 0 & 0 & 0 & 0 & 0 & 0 & 0 & 0 & 0 & 0 & 0 & 0 & 0 & 0 & 0 & 0 \\
\hline Carteret, NC & 34.8846 & -76.6207 & 0 & 0 & 0 & 46 & 0 & 0 & 0 & 0 & 0 & 0 & 0 & 0 & 0 & 0 & 0 & 0 & 0 & 0 & 0 \\
\hline & & & & & & & & & & & & & & & & & & \multicolumn{4}{|c|}{ (continued on next page } \\
\hline
\end{tabular}


from Canada (Fig. 2). The majority of the observations occurred in September and October (Fig. 3).

Correspondence between detection of $P$. pachyrhizi in rain samples and IAMS predictions. The detection of $P$. pachyrhizi in rain samples from the continental interior was compared to the IAMS wet deposition predictions for the 15 and 19 weeks in 2007 and 2008, respectively, for which spore data from the NADP/NTN and Canadian networks are available. It should be noted that $P$. pachyrhizi detection in rain samples and IAMS SBR spore deposition predictions are not strictly comparable. The spore samples from the rain collection network represent point observations, whereas the spatial resolution of the IAMS predictions is approximately $10 \mathrm{~km}^{2}$. Summertime precipitation is often highly variable over short distances, and consequently spore deposition observations from a single collector may not represent well the deposition of spores within a larger area such as a county. In contrast, the IAMS is very sensitive to the parameterization of the inoculum source region. The accuracy of the aerobiology model spore deposition predictions decreases dramatically as the number and extent of unreported SBR infections in potential source regions increase. Unknown $P$. pachyrhizi infestations in Mexico and/or the Caribbean islands as well as in the southern United States could cause substantial IAMS spore deposition prediction errors early in the growing season for the continental interior region (35). In addition, the IAMS predicts deposition of viable $P$. pachyrhizi spores while the rain network collects both viable and nonviable spores. For these reasons, the output from the model and data from the rain collectors are complementary.

Rain samples with trace and low spore loads of P. pachyrhizi and IAMS deposition predictions with trace and low densities of spores are difficult to interpret with respect to SBR spread. The assumptions in the IAMS concerning spore transport and deposition result in enough ambiguity that a trace or low prediction may or may not be significant with regard to SBR disease spread. Spores collected in rain water samples may or may not be viable. This uncertainty in viability contributes ambiguity to the interpretation of trace and low observations. Because of these observation and modeling shortcomings, a week was considered affirmative for $P$. pachyrhizi transport if one or more rain samples from monitoring sites in the continental interior region recorded a moderate $P$. pachyrhizi spore load (high levels of spores were not recorded in samples from the region during the study period). Similarly, a week was considered affirmative for $P$. pachyrhizi transport if the IAMS wet deposition of viable spores output map indicated a

Table 2. (continued from previous page)

\begin{tabular}{|c|c|c|c|c|c|c|c|c|c|c|c|c|c|c|c|c|c|c|c|c|c|}
\hline Station & Lat. & Long. & $\sum_{\Xi}^{\Xi}$ & 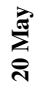 & 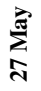 & $\underset{m}{\Xi}$ & $\underset{\Xi}{\Xi}$ & $\stackrel{\Xi}{\Xi}$ & $\underset{\Xi}{\Xi}$ & $\Xi$ & $\underset{\infty}{\Xi}$ & $\underset{\Xi}{\Xi}$ & 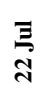 & $\underset{\mathrm{\Xi}}{\mathbf{3}}$ & $\sum_{n}^{00}$ & $\begin{array}{l}\stackrel{00}{E} \\
\beth\end{array}$ & $\begin{array}{l}\stackrel{00}{E} \\
a \\
=\end{array}$ & 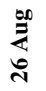 & $\begin{array}{l}\text { Oें } \\
\text { N } \\
\text { N }\end{array}$ & $\begin{array}{l}\text { ๊ } \\
\text { బ }\end{array}$ & $\begin{array}{l}\text { ڤે } \\
\text { బै }\end{array}$ \\
\hline Rowan, NC & 35.6970 & -80.6225 & 0 & 0 & 0 & 6 & 0 & 0 & 0 & 0 & 0 & 0 & 0 & 0 & 0 & 0 & 0 & 0 & 0 & 0 & 0 \\
\hline Sampson, NC & 35.0258 & -78.2783 & 0 & 0 & 0 & 0 & 0 & 0 & 0 & 0 & 0 & 0 & 0 & 0 & 0 & 0 & 0 & 0 & 0 & 32 & 0 \\
\hline Stutsman, ND & 47.1247 & -99.2381 & 0 & 0 & 0 & 0 & 0 & 0 & 0 & 0 & 0 & 0 & 0 & 0 & 0 & 0 & 0 & 0 & 0 & 0 & 0 \\
\hline Lincoln, NE & 41.0592 & -100.7464 & 0 & 0 & 0 & 0 & 0 & 0 & 0 & 0 & 0 & 0 & 0 & 0 & 0 & 0 & 0 & 0 & 0 & 0 & 0 \\
\hline Saunders, NE & 41.1528 & -96.4912 & 0 & 0 & 0 & 0 & 0 & 0 & 0 & 0 & 0 & 0 & 0 & 0 & 0 & 0 & 0 & 0 & 0 & 0 & 0 \\
\hline Cayuga, NY & 42.7339 & -76.6597 & 0 & 0 & 0 & 0 & 0 & 0 & 0 & 0 & 25 & 0 & 0 & 0 & 0 & 0 & 18 & 0 & 0 & 0 & 0 \\
\hline Butler, $\mathrm{OH}$ & 39.5314 & -84.7242 & 0 & 0 & 0 & 0 & 0 & 0 & 0 & 0 & 0 & 0 & 0 & 0 & 0 & 0 & 0 & 0 & 0 & 0 & 0 \\
\hline Crawford, $\mathrm{OH}$ & 40.9170 & -82.9981 & 0 & 0 & 0 & 0 & 0 & 0 & 0 & 43 & 0 & 0 & 0 & 0 & 0 & 0 & 0 & 0 & 0 & 0 & 0 \\
\hline Delaware, $\mathrm{OH}$ & 40.3553 & -83.0661 & 0 & 0 & 0 & 0 & 31 & 0 & 0 & 0 & 0 & 0 & 0 & 0 & 0 & 0 & 0 & 0 & 0 & 0 & 131 \\
\hline Noble, $\mathrm{OH}$ & 39.7928 & -81.5311 & 0 & 0 & 0 & 0 & 22 & 0 & 17 & 0 & 0 & 0 & 0 & 0 & 0 & 46 & 0 & 0 & 0 & 0 & 0 \\
\hline Pickaway, $\mathrm{OH}$ & 39.6358 & -83.2600 & 0 & 0 & 0 & 0 & 0 & 0 & 71 & 0 & 0 & 0 & 27 & 0 & 0 & 0 & 0 & 6 & 0 & 0 & 56 \\
\hline Wayne, $\mathrm{OH}$ & 40.7822 & -81.9200 & 0 & 0 & 0 & 0 & 0 & 0 & 0 & 0 & 0 & 0 & 0 & 0 & 0 & 173 & 0 & 0 & 0 & 0 & 0 \\
\hline Alfalfa, OK & 36.8053 & -98.2006 & 0 & 0 & 0 & 0 & 0 & 0 & 0 & 0 & 0 & 0 & 0 & 0 & 0 & 0 & 0 & 0 & 0 & 0 & 0 \\
\hline McClain, OK & 34.9800 & -97.5214 & 0 & 0 & 0 & 0 & 0 & 0 & 0 & 0 & 0 & 0 & 0 & 0 & 0 & 0 & 0 & 0 & 0 & 0 & 0 \\
\hline Centre, PA & 40.7883 & -77.9458 & 0 & 0 & 0 & 0 & 0 & 0 & 0 & 20 & 10 & 0 & 0 & 0 & 0 & 0 & 0 & 0 & 0 & 0 & 0 \\
\hline Charleston, SC & 32.9419 & -79.6591 & 0 & 0 & 0 & 0 & 0 & 0 & 0 & 18 & 0 & 0 & 0 & 0 & 0 & 0 & 0 & 0 & 0 & 0 & 0 \\
\hline Clarendon, SC & 33.5394 & -80.4350 & 0 & 0 & 0 & 0 & 0 & 0 & 0 & 32 & 0 & 1 & 0 & 0 & 0 & 0 & 0 & 0 & 0 & 0 & 0 \\
\hline Colleton, SC & 32.5993 & -80.4554 & 0 & 0 & 0 & 0 & 0 & 0 & 0 & 0 & 0 & 0 & 0 & 0 & 0 & 0 & 0 & 0 & 0 & 0 & 0 \\
\hline Beadle, SD & 44.3550 & -98.2917 & 0 & 0 & 0 & 0 & 0 & 0 & 0 & 17 & 0 & 0 & 0 & 0 & 0 & 0 & 0 & 0 & 0 & 0 & 0 \\
\hline Jackson, SD & 43.9461 & -101.8552 & 0 & 0 & 0 & 0 & 30 & 0 & 0 & 0 & 0 & 0 & 0 & 0 & 0 & 0 & 0 & 0 & 0 & 0 & 288 \\
\hline Anderson, TN & 35.9614 & -84.2872 & 0 & 0 & 0 & 0 & 0 & 0 & 0 & 0 & 0 & 0 & 0 & 0 & 0 & 0 & 0 & 0 & 0 & 0 & 0 \\
\hline Haywood, TN & 35.4678 & -89.1586 & 0 & 0 & 0 & 0 & 0 & 0 & 0 & 0 & 0 & 0 & 0 & 0 & 0 & 21 & 0 & 0 & 0 & 0 & 190 \\
\hline Bee, TX & 28.4667 & -97.7069 & 0 & 0 & 0 & 0 & 0 & 0 & 66 & 0 & 20 & 0 & 0 & 0 & 0 & 0 & 0 & 0 & 0 & 0 & 0 \\
\hline Colorado, TX & 29.6614 & -96.2594 & 0 & 0 & 0 & 0 & 0 & 0 & 0 & 0 & 0 & 0 & 0 & 0 & 0 & 0 & 0 & 0 & 0 & 0 & 0 \\
\hline Culberson, TX & 31.9083 & -104.8028 & 0 & 0 & 0 & 0 & 0 & 0 & 0 & 0 & 26 & 7 & 0 & 0 & 0 & 0 & 0 & 0 & 0 & 0 & 0 \\
\hline Edwards, TX & 30.2614 & -100.5550 & 0 & 0 & 0 & 0 & 0 & 0 & 0 & 0 & 0 & 0 & 0 & 0 & 0 & 0 & 0 & 0 & 0 & 0 & 0 \\
\hline Gregg, TX & 32.3786 & -94.7117 & 0 & 0 & 0 & 0 & 0 & 0 & 0 & 0 & 0 & 0 & 0 & 0 & 0 & 78 & 0 & 0 & 0 & 0 & 0 \\
\hline Wise, TX & 33.3917 & -97.6397 & 0 & 0 & 0 & 0 & 0 & 0 & 0 & 0 & 0 & 0 & 0 & 0 & 0 & 125 & 0 & 0 & 0 & 0 & 199 \\
\hline Albemarle, VA & 38.0402 & -78.5427 & 0 & 0 & 0 & 0 & 0 & 0 & 0 & 0 & 0 & 0 & 0 & 0 & 0 & 0 & 0 & 0 & 0 & 0 & 0 \\
\hline Giles, VA & 37.3294 & -80.5579 & 0 & 0 & 0 & 0 & 0 & 0 & 22 & 10 & 20 & 0 & 0 & 0 & 0 & 129 & 0 & 0 & 0 & 47 & 0 \\
\hline Taylor, WI & 45.2064 & -90.5978 & 0 & 0 & 0 & 0 & 0 & 0 & 0 & 0 & 0 & 0 & 0 & 0 & 0 & 0 & 0 & 0 & 0 & 0 & 179 \\
\hline Vernon, WI & 43.7023 & -90.5685 & 0 & 0 & 0 & 0 & 0 & 0 & 0 & 22 & 0 & 0 & 0 & 0 & 0 & 0 & 0 & 0 & 0 & 15 & 274 \\
\hline Walworth, WI & 42.5792 & -88.5006 & 0 & 0 & 0 & 0 & 0 & 0 & 0 & 40 & 0 & 0 & 0 & 0 & 0 & 0 & 0 & 0 & 0 & 0 & 0 \\
\hline Lacombe, AB & 52.4502 & -113.7549 & - & - & - & 0 & 0 & 0 & 0 & 0 & 0 & 0 & 0 & 0 & 0 & 0 & 0 & 0 & 0 & 0 & 0 \\
\hline Morden, MB & 49.1875 & -98.0838 & - & - & - & 0 & 0 & 0 & 0 & 0 & 11 & 0 & 3 & 0 & 0 & 0 & 0 & 0 & 0 & 0 & 0 \\
\hline Beloeil, ON & 45.5768 & -73.2409 & - & - & - & 0 & 0 & 0 & 0 & 14 & 8 & 0 & 0 & 0 & 0 & 0 & 0 & 0 & 0 & 0 & 0 \\
\hline Caledonia, ON & 43.0948 & -79.9612 & - & - & - & 0 & 0 & 0 & 0 & 0 & 8 & 0 & 0 & 0 & 0 & 0 & 0 & 0 & 0 & 0 & 0 \\
\hline Forest, ON & 43.0542 & -82.0631 & - & - & - & 0 & 0 & 0 & 0 & 0 & 13 & 0 & 0 & 0 & 3 & 0 & 0 & 0 & 0 & 0 & 0 \\
\hline Harrow, ON & 42.0329 & -82.8963 & - & - & - & 0 & 0 & 0 & 0 & 0 & 0 & 0 & 0 & 0 & 0 & 0 & 0 & 0 & 0 & 0 & 0 \\
\hline Lacolle, ON & 45.0583 & -73.3792 & - & - & - & 0 & 0 & 0 & 0 & 16 & 0 & 0 & 0 & 0 & 0 & 0 & 0 & 0 & 0 & 0 & 0 \\
\hline Morrisburg, ON & 44.9208 & -75.2027 & - & - & - & 0 & 0 & 0 & 0 & 0 & 0 & 0 & 0 & 0 & 0 & 0 & 0 & 0 & 0 & 0 & 0 \\
\hline Ottawa, ON & 45.3900 & -75.7190 & - & - & - & 0 & 0 & 0 & 0 & 12 & 34 & 0 & 0 & 0 & 0 & 0 & 0 & 0 & 5 & 0 & 0 \\
\hline Ridgetown, ON & 42.4559 & -81.8824 & - & - & - & 0 & 0 & 0 & 0 & 42 & 39 & 0 & 0 & 0 & 0 & 0 & 0 & 1 & 0 & 0 & 0 \\
\hline St Thomas, ON & 42.8138 & -81.1205 & - & - & - & 0 & 0 & 0 & 0 & 8 & 5 & 0 & 0 & 0 & 0 & 0 & 0 & 0 & 0 & 0 & 0 \\
\hline Toronto, ON & 43.6613 & -79.4013 & - & - & - & 0 & 0 & 0 & 0 & 12 & 8 & 0 & 0 & 0 & 2 & 0 & 0 & 0 & 0 & 0 & 0 \\
\hline Ontario & 42.2118 & -82.7467 & - & - & - & 0 & 0 & 0 & 0 & 0 & 26 & 0 & 0 & 0 & 0 & 0 & 0 & 0 & 0 & 0 & 0 \\
\hline Saskatoon, SK & 52.1167 & -106.6333 & - & - & - & 0 & 0 & 0 & 0 & 0 & 37 & 0 & 0 & 0 & 0 & 0 & 0 & 0 & 0 & 0 & 0 \\
\hline
\end{tabular}




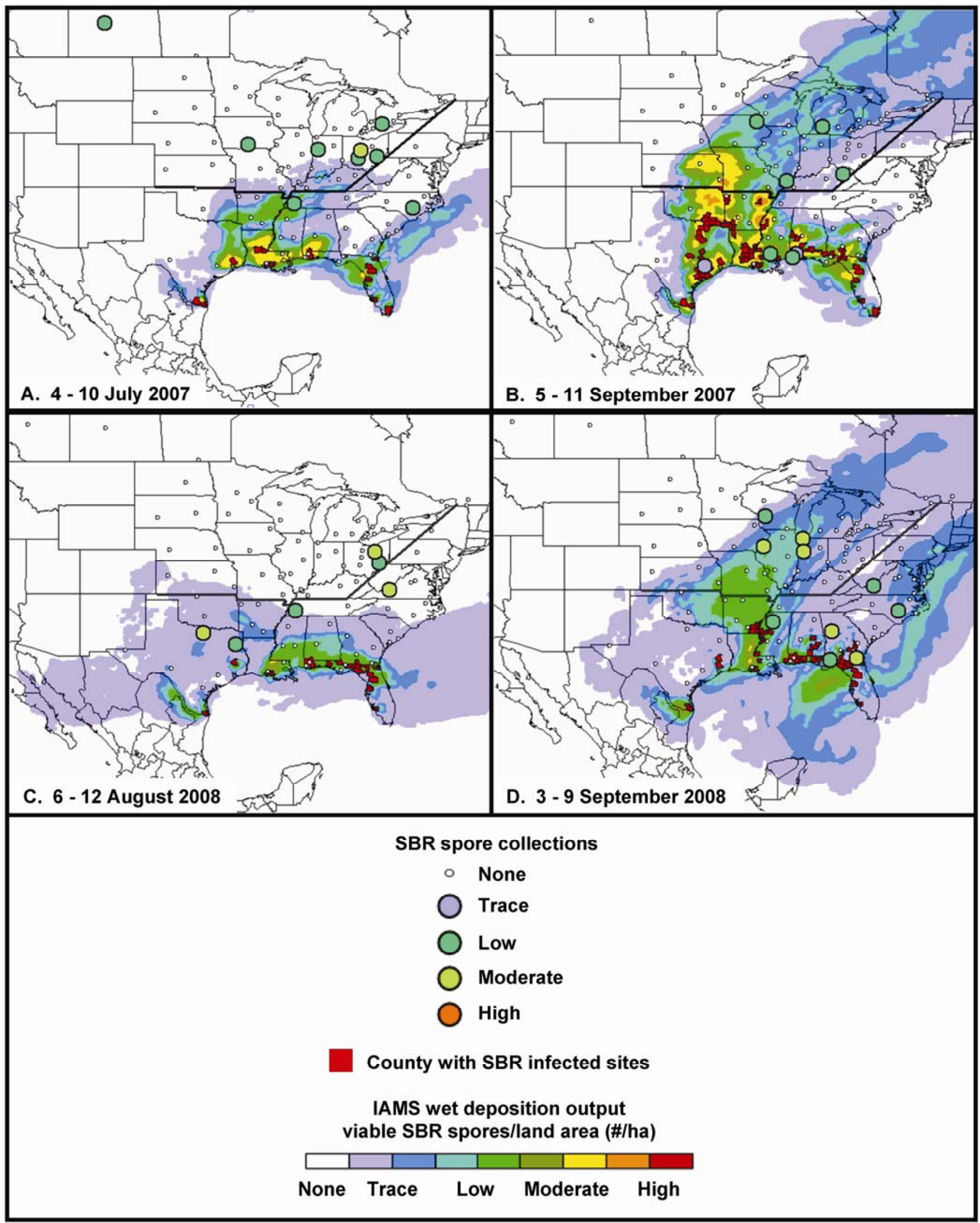

Fig. 4. Maps showing 2007 and 2008 study weeks for which rain samples and Integrated Aerobiology Modeling System (IAMS) output indicating deposition of Phakopsora pachyrhizi urediniospores in the continental interior of North America did not correspond (A, 4-10 July 2007; B, 5-11 September 2007; C, 6-12 August 2008; and D, 3-9 September 2008). The area to the north of the heavy line demarcating the southern borders of Kansas, Missouri, and Kentucky and between the Appalachian and Rocky mountains represents the continental interior of North America for the purposes of this study. Spore load estimates from rain samples are categorized in relative terms as high ( $>430$ spores $/ \mathrm{m}^{2}$ ), moderate (430 to 81 spores $\left./ \mathrm{m}^{2}\right)$, low $\left(80\right.$ to $\left.16 \mathrm{spores} / \mathrm{m}^{2}\right)$, and trace $\left(<15 \mathrm{spores} / \mathrm{m}^{2}\right)$, and IAMS viable spore deposition output is categorized in relative terms as high ( $>10^{5}$ spores/ha), moderate $\left(10^{5}\right.$ to $10^{3}$ spores/ha), low $\left(10^{3}\right.$ to $\left.10^{1} \mathrm{spores} / \mathrm{ha}\right)$, and trace $\left(<10^{1} \mathrm{spores} / \mathrm{ha}\right)$. SBR $=\mathrm{soybean}$ rust. 
moderate or high level of deposition at any location within the region.

P. pachyrhizi urediniospore transport into the continental interior of North America was negative using the moderate/high level deposition criteria for both the rain collection network observations and IAMS predictions during the majority of weeks in the 2007 (9) and 2008 (16) study periods. Both the observations and predictions of $P$. pachyrhizi urediniospore deposition were positive for 4 weeks and 1 week in 2007 and 2008, respectively (Fig. 1). Consequently, the observations and predictions agreed for 87 and $89 \%$ of the 2007 and 2008 sampling periods, respectively. Disagreement between the observations and model output occurred on 4 weeks in the two seasons. In two of these weeks (Fig. 4A and C), there was a single rain sample with a moderate level of $P$. pachyrhizi urediniospores in the continental interior, while the IAMS predicted low deposition in the region. In another case, the IAMS predicted low spore deposition in a large portion of the continental interior, and three rain samples in the region indicated moderate $P$. pachyrhizi spore loads (Fig. 4D). Only in one week (Fig. 4B) was the level of disagreement substantial. In this case, the IAMS predicted moderate to high levels of spore deposition in sections of Kansas, Nebraska, Missouri, and Iowa, but only low levels of P. pachyrhizi spores were detected at four widely dispersed continental interior rain monitoring sites.

Although interpretation of trace and low spore loads in rainwater samples and IAMS deposition predictions with trace and low densities of spores are questionable due to observational and modeling shortcomings, they also display strong correspondence for the study period. The observations and predictions of spore deposition in trace and low categories within the North American continental interior corresponded for 56 and $69 \%$ of the weeks in 2007 and 2008 for which neither the spore deposition observations nor the IAMS spore deposition predictions were in the moderate or high categories (9 and 16 weeks for 2007 and 2008, respectively).

Relationship between observations and predictions of $P$. pachyrhizi urediniospore deposition and SBR incursions into the North American continental interior. Each year since 2005, P. pachyrhizi urediniospores have been blown from the Gulf Coast region, where the pathogen is able to overwinter on kudzu, into the major soybean production region in the North American continental interior where it has infected the soybean crop. Fortunately, these incursions into the continental interior have occurred too late in the growing season to reduce yield and necessitate fungicide applications $(6,25)$. In each year, the scenario of disease spread is similar. (i) The pathogen overwinters along the Gulf Coast on kudzu and on a variety of hosts in Mexico and the Caribbean basin. (ii) The disease spreads into commercial soybean fields in southern states that are typically in their early reproductive stages when and where there is a prolonged period of wet weather and daytime temperatures that are not extremely hot. (iii) Inoculum levels increase to high levels in southern soybean fields and kudzu patches. This increase can be affected by a combination of factors including continuation of wet conditions, shortening day length, onset of cool weather, and/or the maturation of the crop beyond a stage that requires fungicide applications for maintaining yield, and thus the disease is allowed to progress unchecked. (iv) P. pachyrhizi urediniospores are transported to commercial fields in the interior of the North American continent by large-scale southerly airflows associated with tropical or middle latitude storm systems.

In 2007, SBR was identified in the continental interior in the third week of September. Sporulation of SBR had become widespread in eastern Texas, Louisiana, and southern Oklahoma in early to mid-August, approximately 5 to 6 weeks earlier. During this same period, both middle latitude and tropical storm systems with the potential to transport spores long distances into the continental interior impacted the central United States. The long-distance aerial spread of $P$. pachyrhizi into the continental interior occurred about one month later in 2008 than in 2007. Reports of SBR were not prevalent in the southern United States until early September 2008, when the disease became widespread in the Delta region of Arkansas and Mississippi. A series of tropical weather systems that made landfall along the Gulf Coast west of the Mississippi River transported $P$. pachyrhizi urediniospores into the continental interior at this time. As in the previous year, SBR was identified in the continental interior between 30 and 40 days after both the detection in rain samples and IAMS predictions indicated substantial incursions of $P$. pachyrhizi spores into the region (Fig. $1 \mathrm{~B}$ and E). A similar scenario of SBR spread occurred in 2006 $(2,19)$.

Maintaining the effectiveness of the ipmPIPE system for SBR management. A primary goal of a plant disease monitoring network is to provide timely warning of disease spread for the purpose of effective crop management that minimizes fungicide use and maximizes growers' profits. The SBR Sentinel Plot Network has been operating as part of the ipmPIPE system since 2005 in the soybean production regions of the United States and Canada and was expanded into Mexico in 2007. Over that period, the system has been very successful at: (i) providing early warning to soybean producers in the southern United States of the need to spray fields to protect their crop yields, and (ii) reassuring extension specialists, crop consultants, and soybean growers in the continental interior of North America, at times when their crop was susceptible to significant yield loss from SBR, that their fields were not at risk. This information has been needed to counter occasional rumors of SBR incursions into the continental interior and has likely saved the use of fungicides that would have been applied unnecessarily to millions of soybean acres (31).

Li et al. (25) argue that neither high daytime air temperatures nor opportunities for spore dispersal are responsible for limiting SBR spread in North America. Noting that day length in summer is substantial in the high-latitude regions of North America, they suggest that the late season spread into the continental interior may be associated with suppression of the disease by long day length in June and July. Exposure to sunlight has a detrimental effect on $P$. pachyrhizi spore viability germination and infection efficiencies $(15,26)$. Our spore sampling data from rain collections throughout the continental interior support the assertion that the risk of soybean rust spread in North America is low from May through midAugust and then increases dramatically (Fig. 5). Although samples with low and trace levels of spores occur in the region throughout the summer, samples with moderate level only occurred in the late season. Given the high sensitivity of $P$. pachyrhizi urediniospores to sunlight and the length of exposure during their 75- to 100-h aerial journey from the Gulf Coast to the continental interior, one

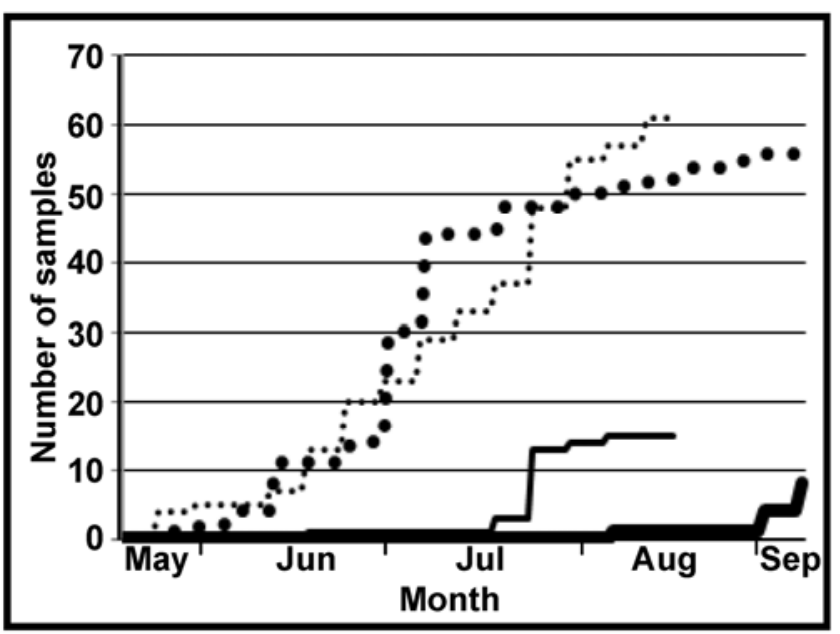

Fig. 5. Temporal distribution of samples from rain collectors located in the continental interior of North America that tested positive for Phakopsora pachyrhizi urediniospores in 2007 and 2008. The lines composed of small and large dots represent 2007 and 2008 samples with trace and low urediniospore levels, respectively. The thin and thick solid lines represent 2007 and 2008 samples with moderate urediniospore levels, respectively. 
must assume that most spores are nonviable upon deposition in the continental interior, even if traveling under cloudy conditions (15). In addition, Dufault et al. (8) report that only 10 to $25 \%$ of $P$. pachyrhizi urediniospores wet deposited on soybean foliage during heavy summer rains are retained long enough to germinate and infect. These considerations suggest that the risk of soybean rust establishment in the continental interior from trace and low spore deposition events may be minimal, highlighting the importance of moderate and high level spore deposition events to disease spread.

The experience of the North American response to the soybean rust incursion has given rise to the proposal that the online information derived from the combination of sentinel plot monitoring, spore trapping, and aerobiology model simulations may be providing coordinated, continent-wide control of soybean rust. This thesis purports that distribution of this information through the ipmPIPE and other communication networks results in effective soybean rust management in the southern United States. Efficacious management coupled with the adverse effects of high levels of solar radiation on soybean rust disease development during June and July may retard the production of $P$. pachyrhizi inoculum and the subsequent northward movement of spores into the continental interior.

Beginning with the first documented evidence of $P$. pachyrhizi in sentinel plots planted to soybean in southern states during early summer, timely monitoring and targeted fungicide applications in local commercial fields control a variety of diseases until pod set in late summer. These applications keep $P$. pachyrhizi inoculum levels low, with the result that the numbers of spores produced are insufficient to threaten the larger soybean production acreage in the interior of the United States and Canada (6). Once soybeans in southern fields reach the late bean fill stage, fungicide applications cease and the disease begins to spread aggressively in southern commercial fields and neighboring kudzu patches where environmental conditions are conducive to infection. Both tropical and middle latitude weather systems have the potential to move large numbers of spores northward. However, by late summer when this movement occurs, soybean plants within the continental interior are in their late stages of development with little economic vulnerability to disease. In short, the soybean rust Sentinel Plot Network and ipmPIPE information delivery system enables control of soybean rust in southern commercial fields. Timely control practices suppress the buildup of inoculum and retard the subsequent spore movement northward, protecting the substantial acreage of soybean produced in the North American continental interior. The assurance provided by the monitoring network, aerobiology model output, and spore collections to extension specialists, crop consultants, and soybean growers in northern production areas that their fields are not at risk during the summer is an additional benefit providing substantial savings to North American soybean growers (9).

The argument is growing that the cost of maintaining the SBR Sentinel Plot Network throughout the entire North American soybean production region is too high to be sustainable given that SBR has not caused measurable yield reduction in the continental interior since its incursion into the continent. In 2010 and 2011, the United Soybean Board funded monitoring of sentinel plots in southern states while the USDA supported the ipmPIPE communication and information delivery functions. Monitoring of sentinel plots for SBR in most northern states was discontinued, although local soybean grower groups provided support for monitoring in some states and in Ontario. Continued grower association funding for SBR sentinel plot monitoring in Gulf Coast states coupled with USDA support for the IT platform should enable early warning to soybean growers in the southern United States of the need to spray fields in the future. However, given the delayed transport of spores in numbers that are injurious during a growing season, rain collectors may suffice as the only monitoring network in the North American continental interior.

Irrespective of the mix of sentinel plots and spore trapping, some form of SBR monitoring is required over the entire North American soybean acreage. Aerobiology models, such as the IAMS and
St. Louis University/Iowa State University Rust Prediction Model (29), are highly dependent on accurate knowledge of the geographic distribution and intensity of $P$. pachyrhizi spore production in the United States, Mexico, and Caribbean basin. Parameterization of these models using disease observations from a monitoring network in the Gulf Coast states is necessary to predict $P$. pachyrhizi spore transport and subsequent disease development in continental interior soybean production regions. Another important value of a spore trapping system in the continental interior and aerobiology modeling is the assurance given to crop consultants and extension specialists that conditions are not right for SBR incursions and that consequently growers may avoid the cost and effort of applying a fungicide for SBR control.

As a final note, there may be an additional advantage for relying on rain collectors as part of the SBR monitoring network in the North American continental interior. Spore collections for rainwater samplers can be important components of biosecurity monitoring networks (21). The expansion of the PCR analysis of rain samples from this network to include multiple airborne pathogens that cause corn rusts (Puccinia sorghi and Puccinia polysora) and wheat rusts (Puccinia graminis, Puccinia striiformis, and Puccinia triticina), in addition to $P$. pachyrhizi, could make an important contribution to North American biosecurity.

\section{Acknowledgments}

We thank the hundreds of individuals who have collected and analyzed observations from SBR sentinel plots and the NADP and Canadian rain collection networks. The research was supported by the United Soybean Board and the U.S. Department of Agriculture, Agricultural Research Service, Risk Management Agency, Cooperative States Research Education, and Extension Service (now National Institute for Food and Agriculture), and Animal and Plant Health Inspection Service. The Ontario soybean rust sentinel and mobile monitoring program and the rain collection network were supported by the Grain Farmers of Ontario, which obtained funding through the Farm Innovation Program, a component of Growing Forward. Additional support was provided by the Ontario SBR coalition, which obtained funding through the CanAdvance Program. Both the Farm Innovation and CanAdvance Programs are administered by the Agricultural Adaptation Council.

\section{Literature Cited}

1. Aylor, D. E. 1986. A framework for examining inter-regional aerial transport of fungal spores. Agric. For. Meteorol. 38:263-288.

2. Barnes, C. W., Szabo, L. J., and Bowersox, V. C. 2009. Identifying and quantifying Phakopsora pachyrhizi spores in rain. Phytopathology 99:328338.

3. Bonde, M. R., Nester, S. E., Berner, D. K., Frederick, R. D., Moore, W. F. and Little, S. 2008. Comparative susceptibilities of legume species to infection by Phakopsora pachyrhizi. Plant Dis. 92:30-36.

4. Bradley, C. A., Allen, T. W., Dorrance, A. E., Dunphy, E. J., Giesler, L. J. Hershman, D. E., Hollier, C. A., Horn, V., and Wrather, J. A. 2010. Evaluation of the Soybean Rust Pest Information Platform for Extension and Education (PIPE) Public Website's Impact on Certified Crop Advisers. Plant Health Progress. doi:10.1094/PHP-2010-0701-01-RS.

5. Cardwell, K. F. 2006. Current policy perspectives from CSREES and APHIS. 2nd National SBR Symposium, American Phytopathological Society. http://www.plantmanagementnetwork.org/infocenter/topic/soybeanrust/ 2006/presentations/Cardwell.pdf.

6. Dorrance, A., Hershman, D., and Draper, M. 2007. Economic importance of SBR. Pages 11-19 in: Using Foliar Fungicides to Manage SBR. A. E. Dorrance, M. A. Draper, and D. E. Hershman, eds. The Ohio State University, Columbus.

7. Dossett, S. R., and Bowersox. V. C. 1999. National Trends Network Site Operations Manual. National Atmospheric Deposition Program Office at the Illinois State Water Survey. NADP Manual 1999-01. Champaign, IL.

8. Dufault, N. S., Isard, S. A., Marois, J. J., and Wright, D. L. 2010. Removal of wet deposited Phakopsora pachyrhizi urediniospores from soybeans by subsequent rainfall. Plant Dis. 94:1336-1340.

9. Giesler, L. J., and Hershman, D. E. 2007. Overview and value of sentinel plots for 2007. 2nd National SBR Symposium, American Phytopathological Society. http://www.plantmanagementnetwork.org/infocenter/topic/soybean rust/2007/presentations/Giesler.pdf

10. Hambleton, S., Tenuta, A., Anderson, T., Tropiano, R., Bergeron, J., and Van Herk, C. 2007. Asian SBR Monitoring Program Pays Off in 2007 with First Detections in Canada. 2007 National SBR Symposium, American Phytopathological Society. http://www.plantmanagementnetwork.org/info center/topic/soybeanrust/2007/posters/.

11. Harman, P., and Harman, C. 2005. PCR, detection times compared to ELISA. 1st National SBR Symposium, American Phytopathological Society. http://www.plantmanagementnetwork.org/infocenter/topic/soybeanrust/ 
symposium/presentations/Harmon.pdf.

12. Haudenshield, J. S., Chadhary, P., and Hartman, G. L. 2009. Recovery of Phakopsora pachyrhizi urediniospores from passive spore trap slides and extraction of their DNA for quantitative PCR. http://www.apsnet.org/ members/divisions/nc/meetings/Pages/2009MeetingAbstracts.aspx.

13. Hershman, D. E., and Giesler, L. J. 2005. Overview of Sentinel Monitoring System for 2005: How well did we do? 1st National SBR Symposium, American Phytopathological Society. http://www.plantmanagementnetwork. org/infocenter/topic/soybeanrust/symposium/presentations/Giesler.pdf.

14. Hoffman, W. 2005. USDA Cooperative State Research, Education, and Extension Service (CSREES) Perspective. 1st National SBR Symposium, American Phytopathological Society. http://www.plantmanagementnetwork. org/infocenter/topic/soybeanrust/symposium/presentations/hoffman.pdf.

15. Isard, S. A., Dufault, N. S., Miles, M. R., Hartman, G. L., Russo, J. M., De Wolf, E. D., and Morel, W. 2006. The effect of solar irradiance on the mortality of Phakopsora pachyrhizi urediniospores. Plant Dis. 90:941-945.

16. Isard, S. A., Gage, S. H., Comtois, P., and Russo, J. M. 2005. Principles of aerobiology applied to SBR as an invasive species. BioScience 55:851-862.

17. Isard, S. A., and Russo, J. M. 2007. Evaluation of the 2007 ensemble forecasting program. 2nd National SBR Symposium, American Phytopathological Society. http://www.plantmanagementnetwork.org/infocenter/topic/ soybeanrust/2007/presentations/Isard.pdf.

18. Isard, S. A., and Russo, J. M. 2007. Sentinel plots in the United States: Modeling the seasonal spread of SBR in North America. Pages 39-40 in: Using Foliar Fungicides to Manage SBR. A. E. Dorrance, M. A. Draper, and D. E. Hershman, eds. The Ohio State University, Columbus.

19. Isard, S. A., Russo, J. M., and Ariatti, A. 2007. Aerial transport of SBR spores into the Ohio River Valley during September 2006. Aerobiologia 23:271-282.

20. Isard, S. A., Russo, J. M., and DeWolf, E. D. 2006. The establishment of a national pest information platform for extension and education. Online, Plant Health Progress, doi:10.1094/PHP-2006-0915-01-RV.

21. Jackson, S. L., and Bayliss, K. L. 2011. Spore traps need improvement to fulfill plant biosecurity requirements. Online, Plant Pathology doi:10.1111/ j.1365-3059.2011.02445.x

22. Jurick, W. M., II, Narvaez, D. F., Brennan, M. M., Harmon, C. L., Marois, J. J., Wright, D. L., and Harmon, P. F. 2008. Winter survival of the SBR pathogen, Phakopsora pachyrhizi, in Florida. Plant Dis. 92:1551-1558.

23. Krupa, S., Bowersox, V., Claybrooke, R., Barnes, C. W., Szabo, L., Harlin, K., and Kurle, J. 2006. Introduction of Asian SBR urediniospores into the Midwestern United States-a case study. Plant Dis. 90:1254-1259.

24. Lamour, K. H., Finley, L., Snover-Clift, K. L., Stack, J. P., Pierzynski, J.,
Hammerschmidt, R., Jacobs, J. L., Byrne, J. M., Harmon, P. F., Vitoreli, A. M., Wisler, G. C., Harmon, C. L., Levy, L., Zeller, K. A., Stone, C. L., Luster, D. G., and Frederick, R. D. 2006. Early detection of Asian SBR using PCR. Online. Plant Health Progress doi:10.1094/PHP-2006-0524-01-RS.

25. Li, X., Esker, P. D., Pan, Z., Dias, A. P., Xue, L., and Yang, X. B. 2010. The uniqueness of the soybean rust pathosystem: An improved understanding of the risk in different regions of the world. Plant Dis. 94:796-806.

26. Li, X., Mo, J., Guo, T., and Yang, X. 2010. Effects of light on urediniospore germination, appressorium formation and infection efficiency of Phakopsora pachyrhizi, causal agent of soybean rust. Can J. Plant Pathol. 32:153161.

27. Marchetti, M. A., Uecker, F. A., and Bromfield, K. R. 1975. Uredial development of Phakopsora pachyrhizi in soybeans. Phytopathology 65:822-823.

28. Miles, M. R., Frederick, R. D., and Hartman, G. L. 2003. SBR: Is the U.S. soybean crop at risk? American Phytopathological Society. APSnet Features. Online. doi:10.1094/APSnetFeature-2003-0603.

29. Pan, Z., Yang, X. B., Pivonia, S., Xue, L., Pasken, R., and Roads, J. 2006. Long-term prediction of SBR entry into the continental United States. Plant Dis. 90:840-846.

30. Park, S., Chen, Z.-Y., Chanda, A. K., Schneider, R. W., and Hollier, C. A 2008. Viability of Phakopsora pachyrhizi urediniospores under simulated southern Louisiana winter temperature conditions. Plant Dis. 92:1456-1462.

31. Roberts, M. J., Schimmelpfennig, D., Ashley, E., and Livingston, M. 2006. The value of plant disease early-warning systems: A case study of USDA's SBR coordinated framework. U.S. Dep. Agric., Economic Research Service, Economic Research Report No. 18. http://www.ers.usda.gov/ publications/err18/err18fm.pdf.

32. Rowell, J. B., and Romig, R. W. 1966. Detection of urediospores of wheat rusts in spring rains. Phytopathology 56:807-811.

33. Schneider, R. W., Durr, E., and Giles, C. G. 2007. A new spore trap that utilizes electrostatic deposition and scanning electron microscopy. (Abstr.) Phytopathology 97:S105.

34. Schneider, R. W., Hollier, C. A., Whitman, H. K., Palm, M. E., and McKemy, J. M. 2005. First report of SBR caused by Phakopsora pachyrhizi in the continental United States. Plant Dis. 89:774.

35. Tao, Z., Malvick, D., Claybrook, R., Floyd, C., Bernacchi, C. J., Spoden, G., Kurle, J., Gay, D., Bowersox, V., and Krupa, S. 2009. Predicting the risk of soybean rust in Minnesota based on an integrated atmospheric model. Int. J. Biometeorol. 53:509-521.

36. U.S. Dep. Agric. 2011. Integrated Pest Management - Pest Information Platform for Extension and Education. http://sbr.ipmpipe.org/cgi-bin/ sbr/public.cgi. 